\title{
Unraveling the Karenia selliformis complex with the description of a non- gymnodimine producing Patagonian phylotype
}

\author{
Jorge I. Mardones ${ }^{1, *}$, Luis Norambuena ${ }^{1}$, Javier Paredes ${ }^{1}$, Gonzalo Fuenzalida ${ }^{1}$, \\ Juan José Dorantes-Aranda ${ }^{2}$, Kim J. Lee Chang ${ }^{3}$, Leonardo Guzmán ${ }^{1}$, Bernd Krock ${ }^{4}$, \\ Gustaaf Hallegraeff ${ }^{2}$ \\ ${ }^{1}$ Centro de Estudios de Algas Nocivas (CREAN), Instituto de Fomento Pesquero (IFOP), Puerto Montt, Chile \\ ${ }^{2}$ Institute for Marine and Antarctic Studies (IMAS), University of Tasmania, Australia \\ ${ }^{3}$ CSIRO Ocean and Atmosphere, GPO Box 1538, Hobart, TAS, 7001, Australia \\ ${ }^{4}$ Alfred Wegener Institut-Helmholtz Zentrum für Polar- und Meeresforschung, Am Handelshafen 12, 27570 Bremerhaven, Germany
}

\section{A R T I C L E I N F O}

\section{Keywords:}

Phylogeny

SEM

Growth rate

Ichthyotoxicity

ROS and PUFA

LC-MS/MS screening

Pigment composition, Chile

\begin{abstract}
A B S T R A C T
Karenia selliformis is a bloom-forming toxic dinoflagellate known for production of gymnodimines (GYMs) and causing mass mortalities of marine fauna. Blooms have been reported from coastal waters of New Zealand, Mexico, Tunisia, Kuwait, Iran, China and Chile. Based on molecular phylogeny, morphology, toxin production, pigment composition and cell growth of Chilean $K$. selliformis isolated in 2018 (CREAN_KS01 and CREAN_KS02), this study revealed a more complex diversity within this species than previously thought. A phylogenetic reconstruction based on the large sub-unit ribosomal nucleotide (LSU rDNA) and Internal Transcriber Spacer (ITS) sequences of 12 worldwide isolates showed that within the $K$. selliformis clade there are at least two different phylotypes with clear phenotypic differences. Morphological differences related to the dorsal-ventral compression, shape of the hyposome and the presence of pores on the left lobe of the hyposome. A comparison of pigment signatures among worldwide isolates revealed the existence of both acyl-oxyfucoxanthin and fucoxanthin-rich strains within the phylotypes. A LC-MS/MS screening on both Chilean 2018 K. selliformis strains showed for first time no GYMs production among cultured clones of this species. However, both CREAN_KS01 and CREAN_KSO2 contained two compounds with the same mass transition as brevenal, a brevetoxin related compound. A fish gill cell-based assay showed that the CREAN_KS02 strain was highly cytotoxic but pure GYM standard did not exhibit loss of cell viability, even at cell concentrations equivalent or exceeding those reported in nature. The fatty acid profile of CREAN_KS02 included high levels of saturated (14:0; 16:0) and polyunsaturated $(18: 3 \omega 6+18: 5 \omega 3 ; 22: 6 \omega 3)$ fatty acids but superoxide production in this strain was low $\left(0.86 \pm 0.53 \mathrm{pmol} \mathrm{O}_{2}{ }^{-}\right.$cell $\left.^{-1} \mathrm{~h}^{-1}\right)$. A factorial T-S growth experiment using the CREAN_KS02 strain showed a $\mu_{\max }$ of $0.41 \pm 0.03 \mathrm{~d}^{-1}$ at high salinity and temperature, which points to its optimal environmental niche in offshore waters during the summer season. In conclusion, the present study provides evidence for significant genetic and phenotypic variability among worldwide isolates, which points to the existence of a $K$. selliformis "species complex". The massive fauna mortality during $K$. selliformis bloom events in the Chilean coast cannot be explained by GYMs nor brevetoxins, but can to a large extent be accounted for by the high production of longchain PUFAs and/or still uncharacterized highly toxic compounds.
\end{abstract}

\section{Introduction}

The marine dinoflagellate genus Karenia G. Hansen \& Moestrup 2000 is known to produce potent toxins (e.g., brevetoxins, gymnodimines, and undefined ichthyotoxins) that can potentially cause risk for human health and/or marine animal illness and mortality (Brand et al., 2012). Within the family Kareniaceae, which includes the genera
Karlodinium J. Larsen, Takayama de Salas, Bolch et Hallegraeff, Asterodinium Sournia and Brachidinium Sournia, the genus Karenia was circumscribed for species previously contained within the genus Gymnodinium with the type species K. brevis (Davis, 1948) G. Hansen \& Moestrup (Daugbjerg et al., 2000). Other taxa include K. asterichroma Salas, Bolch \& Hallegraeff , $K$. bicuneiformis Botes, Sym \& Pitcher $(=K$. bidigitata Haywood \& Steidinger), K. brevisulcata (F.H.Chang) Gert

\footnotetext{
* Corresponding author.

E-mail address: jorge.mardones@ifop.cl (J.I. Mardones).
} 
Hansen \& Moestrup , K. concordia F.H.Chang \& K.G.Ryan , K. cristata L.Botes, S.D.Sym \& G.C.Pitcher, K. longicanalis Z.B.Yang, I.J.Hodgkiss \& Gert Hansen ( $=K$. umbella Salas, Bolch \& Hallegraeff), K. mikimotoi (Miyake \& Kominami ex Oda) Gert Hansen \& Moestrup , K. papilionacea A.J.Haywood \& K. A. Steidinger, and K. selliformis A.J.Haywood, K. A. Steidinger \& L. MacKenzie. A key characteristic that distinguishes the family Kareniacea is that, instead of peridinin it contains the accessory chloroplast pigments fucoxanthin, 19'-butanoyloxyfucoxanthin, 19'hexanoyloxyfucoxanthin, and 19-hexanoyloxyparacentrone 3-acetate (gyroxanthin-diester) (Hansen et al., 2000; Steidinger et al., 2008a). This property has been previously exploited in routine monitoring programs to facilitate the early detection and tracking of Kareniaceae blooms in coastal waters (Richardson and Pinckney, 2004).

Among the Karenia species, $K$. selliformis appears to be fairly widespread and frequently associated with marine fauna mortality events. Initially described from New Zealand (Haywood et al., 2004), K. selliformis has since been found in Kuwait (Heil et al., 2001), Chile (Guillou et al., 2002), Tunisia (Munday et al., 2004), Gulf of Mexico (Haywood et al., 2007) and China (Li et al., 2018). Among the toxic bioactive compounds produced by $K$. selliformis, gymnodimine-A, GYMB and GYM-C have been well characterized (Seki et al., 1995; Miles et al., 2000; 2003). Gymnodimines (GYMs) alter nicotic actylocholine receptors in muscles (Molgó et al., 2007) and act as neuromuscular blocking agent (Mountfort et al., 2006) resulting in widespread death of both invertebrates and vertebrates. Analytically, GYMs exert potent effects in the mouse bioassay, with high intraperitoneal (LD50 of 80-96 $\mu \mathrm{g} \mathrm{kg}^{-1}$ ) but low oral toxicity (Munday et al., 2004; Kharrat et al., 2008). K. selliformis produced positive enzyme-linked immunosorbent assay (ELISA) results (50-110 $\mathrm{pg} \mathrm{mL}^{-1}$ ) for brevetoxins (Haywood et al., 2004) but this was not confirmed by liquid chromatography-mass spectrometry (LC-MS/MS) (McNabb et al., 2012). Mooney et al., (2007) suggested that most species in Kareniaceae produce ichthyotoxic polyunsaturated fatty acids (PUFAs), the toxicity of which can be enhanced by lipid peroxidation in the presence of reactive oxygen species (ROS). Arzul et al. (1995) found that PUFAs from $K$. mikimotoi are hemolytic. $K$. selliformis has also been shown to produce hemolysins that lyse red blood cells (Tatters et al., 2010), however, neither PUFAs nor ROS production has been studied in $K$. selliformis so far.

The taxonomic history of $K$. selliformis has been complex. A massive fish-kill in the Gulf of Gabès, Tunisia in 1994 was attributed to Gymnodinium maguelonnense, but the species later identified as $K$. selliformis based on molecular and morphological characteristics (Guillou et al., 2002, Hansen et al., 2004). In the Arabian Gulf in 1999, the species responsible for the first fish-kill in the region, initially identified as $G$. cf. mikimotoi using light microscopy, was confirmed to be closely related to the Gymnodinium in New Zealand in 1994, and later identified as K. selliformis (Heil et al., 2001; Haywood et al., 2004; de Salas et al., 2005). In the western Patagonian coast, in summer-fall 1999, a massive bloom of Gymnodiniales killed a large number of marine fauna (Clément et al., 2001; Carreto et al., 2001; Uribe and Ruíz, 2001). The first detection, colloquially known as "brown tide", occurred in March around the Chiloé Archipelago with cell densities of $4-8 \times 10^{6} \mathrm{~L}^{-1}$ (Clément et al., 2001). High salmon mortality was recorded during the outbreak (Clément et al., 2001). A few weeks later, two unidentified Gymnodiniales morphotypes that resembled " $G$. mikimotoi" bloomed in the Magellan fjords (Uribe and Ruíz, 2001). These events constituted the first reports of a Gymnodiniales bloom associated to fauna mortality in the south of Chile. A single cell isolated from the 1999 event from a Lugol-fixed field sample was studied comparing LSU rDNA (GenBank AF318247) with that K. cf. mikimotoi isolated from New Zealand (GenBank U92250) (Guillou et al., 2002) and resolved both isolates to belong to the same clade. Two years later, the $K$. cf. mikimotoi culture (CAWD79 GenBank U92250) from New Zealand was formally described as K. selliformis Haywood, Steidinger et MacKenzie based on phylogenetic analysis and morphological characteristics
(Haywood et al., 2004). However, the Chilean Karenia LSU rDNA sequence by Guillou et al., (2002) was not used in the phylogenetic analysis by Haywood et al., (2004) which generated uncertainty about the species identification from Chilean waters.

In austral summer 2018, a massive bloom of Kareniaceae (hundreds of kilometers wide) killed millions of pelagic and benthic marine animals in the western Patagonian coast (IFOP, unpublished data). Two cytotoxic cultures from that event (hereafter Chilean_2018 strains) (Mardones, 2020), resembled K. selliformis identified by Guillou et al., (2002), but no gymnodimine was detected in either phytoplankton nor mussels from field samples (Guzmán et al., 2020).

The aim of this study was to 1 ) define the systematic position, taxonomy, pigment signature, toxicity and environmental conditions of temperature and salinity for growth of the Karenia selliformis-like isolated from the fauna mortality event in 2018 in the south of Chile, and 2) compare these results against available published data from worldwide $K$. selliformis isolates. The results obtained from this study revealed a significant phylogenetic and phenotypic variability among worldwide isolates, which suggests the existence of a $K$. selliformis "species complex".

\section{Material and methods}

\subsection{Microalgae culture conditions}

Two monoclonal cultures of Karenia selliformis were isolated from the massive 2018 outbreak in southern Chile. The CREAN_KS01strain was isolated from Chiloé Island (Los Lagos Region) in February and the CREAN_KSO2 strain from the Guaitecas archipelago (Aysén Region) in March 2018 (Fig. 1). Both Chilean_2018 strains were maintained in culture at the CREAN-IFOP algae collection in Puerto Montt, Chile. However, only the CREAN_KSO2 strain was used in all experiments since CREAN_KS01 underwent fungi contamination during the experimental period. Non-axenic cultures were grown in L1 medium (Guillard and Ryther, 1962$)$ at $15{ }^{\circ} \mathrm{C}$ in sterile filtered $(0.22 \mu \mathrm{m})$ seawater 35 in salinity (In vitro T-S similar to the conditions at the sampling sites) at $100 \mu \mathrm{mol}$ photon $\mathrm{m}^{-2} \mathrm{~s}^{-1}$ (cool white fluorescence lamps) under a 12:12 h light: dark cycle.

\subsection{DNA extraction, amplification, sequencing and phylogeny}

The Large Subunit (LSU) rDNA D1-D2 region and the Internal Transcriber Spacer region (ITS1 + 5.8s + ITS2) of monoclonal cultures of the two Chilean_2018 strains were sequenced. Cells in each strain were harvested at the exponential phase of growth, concentrated by centrifugation at $1500 \mathrm{~g}$ for $10 \mathrm{~min}$ at $4^{\circ} \mathrm{C}$, the supernatant discarded and the cell pellets incubated at $65^{\circ} \mathrm{C}$ for 1 hours in $10 \mu \mathrm{L}$ Proteinase $\mathrm{K}$ $(10 \mathrm{mg} / \mathrm{mL})$ and $1 \mathrm{~mL}$ cetyltrimethylammonium bromide (CTAB). The LSU (D1-D2) region of the rDNA gene was amplified using the primers D1R and D2C (Edvardsen et al., 2003; Scholin et al., 1994). The PCR protocol included an initial denaturation step of $95^{\circ} \mathrm{C}$ for $1 \mathrm{~min}$, followed by 35 cycles of $95{ }^{\circ} \mathrm{C}$ for $30 \mathrm{~s}, 56{ }^{\circ} \mathrm{C}$ for $30 \mathrm{~s}, 72{ }^{\circ} \mathrm{C}$ for $30 \mathrm{~s}$, followed by a $7 \mathrm{~min}$ extension at $72{ }^{\circ} \mathrm{C}$. For the ITS region, primers designed by Vandersea et al. (2017) were used. The PCR protocol included an initial denaturation step of $95^{\circ} \mathrm{C}$ for $1 \mathrm{~min}$, followed by 35 cycles of $95^{\circ} \mathrm{C}$ for $1 \mathrm{~min}, 60^{\circ} \mathrm{C}$ for $1 \mathrm{~min}, 72^{\circ} \mathrm{C}$ for $2 \mathrm{~min}$, followed by a 7 min extension at $72^{\circ} \mathrm{C}$. The PCR products of both genes were visualized on a $1.5 \%$ agarose gel, then purified using the Illustra GFX PCR DNA and gel band purification kit (GE Healthcare), and sent to Macrogen Sequencing Facility (Macrogen ${ }^{\circledR}$, South Korea) for ribosomal regions sequencing in both directions. Phylogenetic analyses were performed using alignments of $550 \mathrm{bp}$ for LSU rDNA and $580 \mathrm{bp}$ for ITS along with sequences available in GenBank using ClustalW/ Geneious Prime 2019.0.3 (Larkin et al., 2007). Maximum likelihood analyses (ML) were performed using PhyML software (Guindon et al., 2010) and jModeltest was used to identify appropriate models of sequence evolution (LSU and 


\section{A}

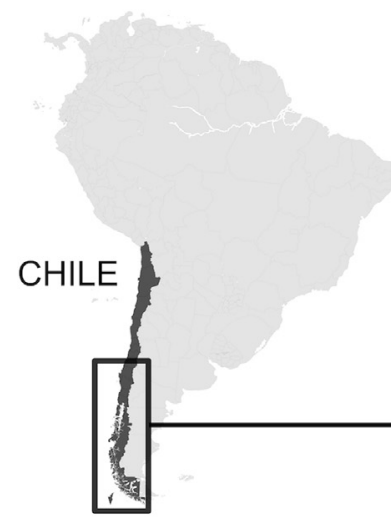

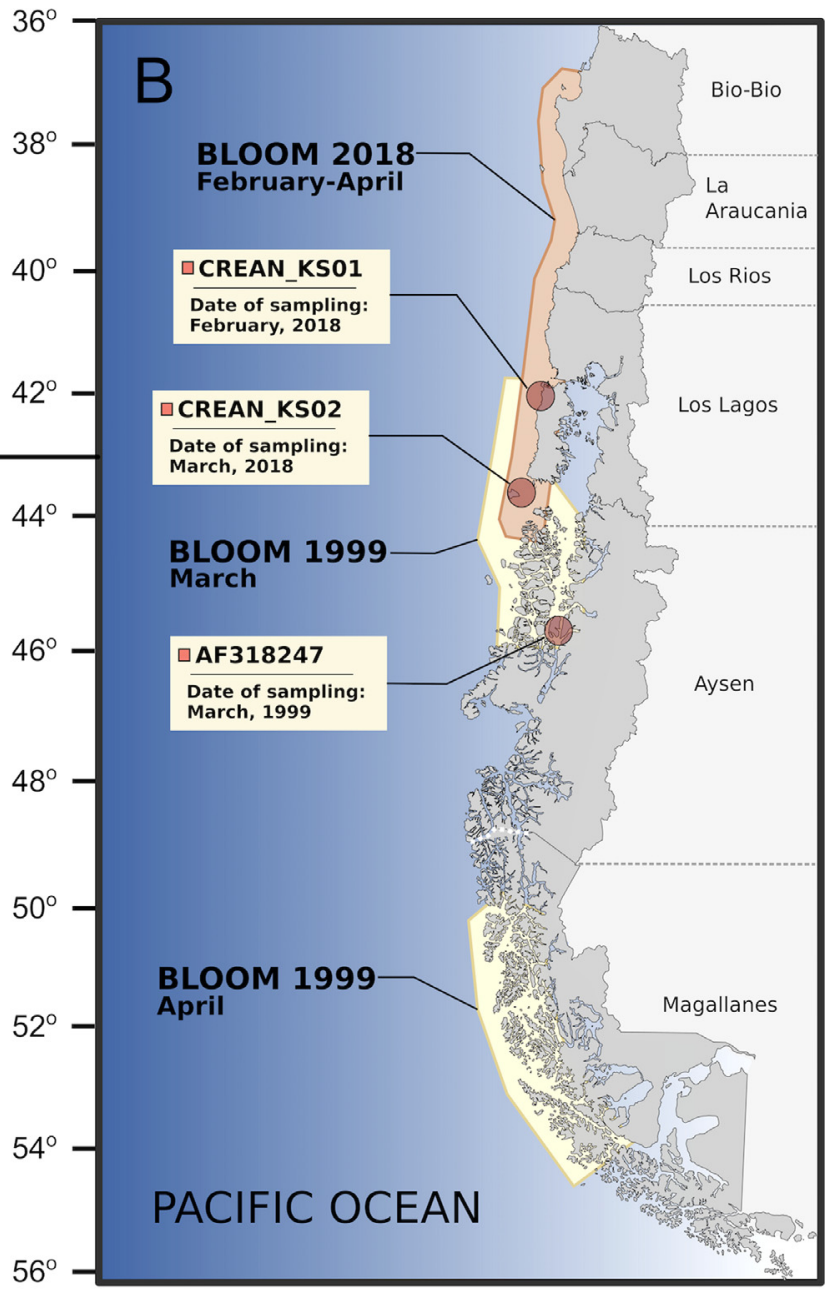

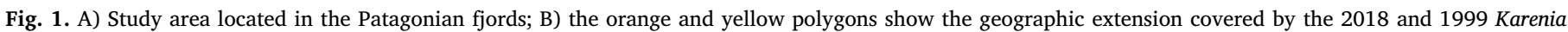
blooms, respectively. The red circles show the sampling sites of the $K$. selliformis sequences presented in this study.

ITS: GTR + I) (Posada, 2008). Node reliability was estimated using Likelihood Ratio Test (aLRT, Anisimova and Gascuel, 2006) and bootstrap analysis (1000 replicates). Finally, bayesian analyses were conducted using MrBayes V3.1.2 under the appropriate model (GTR + I) (Ronquist and Huelsenbeck, 2003).

\subsection{Scanning electron microscopy (SEM)}

Five milliliters of $K$. selliformis KSO2 strain were fixed by adding an equal volume of $4 \% \mathrm{OsO}_{4}$ solution prepared at the same salinity as the sample. Fixed cells were concentrated by gentle centrifugation and then rinsed in culture medium followed by deionized water. Dehydration was carried out using a graded methanol $(10 \%, 30 \%, 50 \%, 70 \%, 90 \%$, $95 \%$, followed by two $100 \%$ dry methanol steps), after which cells were critical-point dried with liquid carbon dioxide and sputter-coated with platinum. Samples were analyzed using a Hitachi SU-70 field emission analytical scanning electron microscope.

\subsection{HPLC pigment analysis}

For pigment analysis, $100 \mathrm{~mL}$ of $K$. selliformis cultures (CREAN_KS02 strain) in exponential growth phase were filtered onto $13 \mathrm{~mm}$ diameter (5.0 $\mu \mathrm{m}$ SVPP) Durapore ${ }^{\circledast}$ membrane filters (Merck Millipore Ltd., Ireland). Cells collected on these filters were subsequently extracted in $1 \mathrm{~mL}$ acetone (100\% - final concentration $\sim 90 \%)$ after probe sonication (60s) and soaking for $24 \mathrm{~h}$ at $-20^{\circ} \mathrm{C}$ as described by Chang et al. (2003).
Photosynthetic pigments were quantified using a Shimadzu high resolution liquid chromatograph (HPLC), with a Sil-10AF auto-sampler, a quaternary LC-10AT pump, DGU-14A degasser, CBM-20A System Controller, and SPD-M20A diode array detector (DAD) as described by Sanz et al. (2015). Chromatographic separation was carried out by using an ACE C18 PFP column $150 \mathrm{~mm}$ x $4.6 \mathrm{~mm}, 3 \mu \mathrm{m}$ particle size (Advanced Chromatography Technologies, Aberdeen, UK) at $40^{\circ} \mathrm{C}$. Mobil phase A was prepared with methanol: $225 \mathrm{mM}$ ammonium acetate (82:12m v:v) and mobile phase B with ethanol. The gradient program was set at a flow rate of $1.0 \mathrm{~mL} \mathrm{~min}^{-1}$. Certified reference standards for alloxanthin (allo), chlorophyll $a$ (chlor-a), chlorophyll $b$ (chlor-b), diatoxanthin (dit), diadinoxanthin (dia), 19-but fucoxanthin (19 but), 19-hex fucoxanthin (19 hex), fucoxanthin (fuco), lutein (lut), 9-cis-neoxanthin (neo), peridinin (per), prasinoxanthin (pra), violaxanthin (vio), zeaxanthin (zea) and mix 122 (mix of 27 pigments used to correct identification of this pigments), were obtained from DHI (DHI Laboratory Products, Hoersholm, Denmark). Ammonium acetate, ethanol and methanol were HPLC gradient grade (Merck; Darmstadt, Germany).

\section{5. $L C-M S / M S$ screening}

In order to determine if brevetoxins (PbTx and BTX) and brevenal were present in the two $K$. selliformis strains, methanolic extracts were analysed on a Waters XEVO TQ-XS tandem quadrupole atmospheric pressure (API) mass spectrometer (Waters, Eschborn, Germany) 
equipped with a high-performance ZSpray dual-orthogonal multi-mode (ESI/SPCI/ESCi) source, coupled to a Waters Acquity UPLC system consisting of a Waters Acquity UPLC I-Class Solvent Manager, a Waters Acquity UPLC I-Class flow-through-needle (FTN) Sample Manager, and a Acquity UPLC I-Class column manager (CM-A) according to GallardoRodriguez et al. (2020). Separation was performed after injection of 0.5 $\mu \mathrm{L}$ sample extract by reversed-phase chromatography on a C18 phase. The analytical column $(50 \times 2.1 \mathrm{~mm})$ was packed with a $130 \AA, 1.7 \mu \mathrm{m}$ $\mathrm{C} 18$ and maintained at $40^{\circ} \mathrm{C}$. The flow rate was $0.6 \mathrm{~mL} \cdot \mathrm{min}^{-1}$ and gradient elution was performed with two eluants, where eluant A was water containing $0.01 \%$ formic acid and $0.05 \%$ ammonium hydroxide, and eluent B was acetonitrile containing $0.01 \%$ formic acid. Initial conditions were 0.5 min column equilibration with $30 \%$ B, followed by a linear gradient to $90 \% \mathrm{~B}$ in $3 \mathrm{~min}$ and isocratic elution until $4 \mathrm{~min}$ with $90 \%$ B. The system was then returned in $0.1 \mathrm{~min}$ to initial conditions (total run time: $5 \mathrm{~min}$ ). Mass spectrometric parameters were as follows: capillary voltage $3.5 \mathrm{kV}$, cone voltage $40 \mathrm{~V}$, desolvation temperature $600^{\circ} \mathrm{C}$, desolvation gas flow $1000 \mathrm{~L} \cdot \mathrm{h}^{-1}$, cone gas flow 150 $\mathrm{L} \cdot \mathrm{h}^{-1}$, nebuliser pressure $7.0 \mathrm{bar}$, collision gas flow $0.15 \mathrm{~mL} \cdot \mathrm{min}^{-1}$, collision $20 \mathrm{eV}$, source temperature $150^{\circ} \mathrm{C}$. Collision induced dissociation (CID) product ion spectra were recorded for the pseudomolecular ion of brevenal $(m / z 657)$. CID spectra were recorded on the same instrument in the ScanWave Daughter scan (ScanWave DS) modus in the mass range from $m / z 50$ to 660 and in positive ionization and unit resolution mode. The following mass spectrometric parameters were applied: capillary voltage $5 \mathrm{kV}$, cone voltage $40 \mathrm{~V}$, desolvation temperature $600^{\circ} \mathrm{C}$, desolvation gas flow $1000 \mathrm{~L} \cdot \mathrm{h}^{-1}$, cone gas flow 150 $\mathrm{L} \cdot \mathrm{h}^{-1}$, nebuliser pressure $7.0 \mathrm{bar}$, collision gas flow $0.15 \mathrm{~mL} \cdot \mathrm{min}^{-1}$, collision energy $30 \mathrm{eV}$, source temperature $150^{\circ} \mathrm{C}$. The mass transitions of brevetoxins and brevenal were set as detailed in Table 1. Gymnodimines were screened on the same instrument and same conditions as for brevetoxins with two modifications: capillary voltage $3.0 \mathrm{kV}$ and collision energy $40 \mathrm{eV}$. Screened GYMs and their mass transitions are given in Table 1.

\subsection{Production of superoxide anion by K. selliformis}

Intact algal cells and lysed cultures of $K$. selliformis (CREAN_KSO2 strain) were examined for production of superoxide anion using the method described by Godrant et al. (2009). Algal cultures were kept at $17^{\circ} \mathrm{C}$ at $100 \mu \mathrm{mol}$ photon $\mathrm{m}^{-2} \mathrm{~s}^{-1}$ (cool white fluorescent lamps) under a 12:12 h light:dark cycle. In a 96-well microplate (CLS3917, Sigma), 3 $\mathrm{mL}$ of xanthine (X7375, Sigma) at $5 \mathrm{mM}$ were mixed with $270 \mathrm{~mL}$ of algal culture. A volume of $3 \mathrm{~mL}$ of superoxide dismutase (S7571, Sigma) at $5 \mathrm{kU} \mathrm{L}^{-1}$ was used for blank correction, and a standard curve was performed using three standard solutions of xanthine oxidase (X1875,

\section{Table 1}

Mass transitions $(m / z$ Q1 $>$ Q3) used for the detection of brevetoxins, brevenal and gymnodimines.

\begin{tabular}{lll}
\hline Toxin & Q1 mass $(m / z)$ & Q3 mass $(m / z)$ \\
\hline PbTx-1 & 867.5 & 849.5 \\
PbTx-2 & 895.5 & 877.5 \\
PbTx-3 & 897.5 & 879.5 \\
PbTx-6 & 911.5 & 893.5 \\
PbTx-7 & 869.5 & 851.5 \\
PbTx-9 & 899.5 & 863.4 \\
PbTx-10 & 871.5 & 853.5 \\
BTX-B1 & 985.5 & 967.5 \\
BTX-B2 & 1034.6 & 1016.6 \\
Brevenal & 657.4 & 639.4 \\
GYM A & 508.3 & 490.3 \\
16-desmethyl GYM D & 510.3 & 492.3 \\
12-methyl GYM A & 522.3 & 504.3 \\
GYM B/C/D & 524.3 & 506.3 \\
GYM E & 526.3 & 508.3 \\
12-methyl GYM B & 538.3 & 520.3 \\
\hline
\end{tabular}

Sigma) at $0.1,0.4$ and $0.7 \mathrm{U} \mathrm{L}^{-1}$. A microplate reader (FLUOstar OPTIMA, BMG Labtech, 413-3350 Germany) was used to monitor luminescence for $20 \mathrm{~min}$ after adding $5 \mathrm{~mL}$ of MCLA, 6-(4-methoxyphenyl)2-methyl-3,7-dihydroimidazo[1,2-a]pyrazin-3(7H)-one hydrochloride (87787, Sigma) at $125 \mathrm{mM}$.

\subsection{Lipid extraction and analysis}

Filters containing the Karenia cultures CREAN_KS02 were extracted using the modified Bligh and Dyer method with dichloromethane/methanol/water (1:2:0.8, v/v/v) as described by Mooney et al. (2007). After phase separation, lipids were recovered in the lower dichloromethane layer and a second extraction performed to maximize lipid recovery. Solvents were removed in vacuo by rotary evaporator. The extracted lipids were transmethylated in methanol/chloroform/ hydrochloric acid $(10: 1: 1, \mathrm{v} / \mathrm{v} / \mathrm{v})$ for $2 \mathrm{~h}$ at $85^{\circ} \mathrm{C}$. After addition of water, the mixture was extracted three times with hexane/chloroform $(4: 1, \mathrm{v} / \mathrm{v})$ to obtain fatty acid methyl esters (FAME), which were concentrated under a stream of nitrogen gas. Samples were prepared to a known volume with the internal injection standard (19:0 FAME) solution, and analyzed by gas chromatography using an Agilent Technologies 7890N GC (Palo Alto, CA, USA) equipped with an Equity-1 crosslinked methyl silicone-fused silica capillary column $(15 \mathrm{~m} \mathrm{x} 0.1 \mathrm{~mm}$ i.d.), and an FID. Helium was used as carrier gas. Samples were injected by a split/splitless injector and an Agilent Technologies 7683B Series autosampler in splitless mode at an oven temperature of $120^{\circ} \mathrm{C}$. After 1 $\min$, the oven temperature was increased to $270^{\circ} \mathrm{C}$ at $10^{\circ} \mathrm{C} \mathrm{min}{ }^{-1}$, then to $310^{\circ} \mathrm{C}$ at $5^{\circ} \mathrm{C} \mathrm{min}^{-1}$. FAME were identified by assessment against retention times of authentic and laboratory standards. Gas chromatography-mass spectrometry (GC-MS) analyses were performed for selected samples for confirmation of FAME identifications using a Finnigan Thermoquest GCQ GC-MS fitted with an on-column injector and using Thermoquest Xcalibur software (Austin, TX, USA). The GC was fitted with a capillary column of similar polarity to that described above.

\subsection{Cytotoxicity}

\subsubsection{Fish gill cell line maintenance}

The cell line RTgill-W1, isolated from gill filaments of rainbow trout Oncorhynchus mykiss (Bols et al., 1994), was acquired from the American Type Culture Collection (CRL-2523, ATCC). Cells were cultured at $17^{\circ} \mathrm{C}$ in the dark in Leibovitz's L-15 medium (L1518 Sigma), supplemented with $10 \%$ (v/v) fetal bovine serum (FBS, 12003C, Sigma), and an antibiotic-antimycotic solution (A5955, Sigma) containing streptomycin $\left(10 \mathrm{mg} \mathrm{mL}^{-1}\right)$, amphotericin $\mathrm{B}\left(25 \mathrm{mg} \mathrm{mL}^{-1}\right)$ and penicillin $\left(10,000\right.$ units $\left.\mathrm{mL}^{-1}\right)$ in $25-\mathrm{cm}^{2}$ culture-treated flasks (3100-025, Iwaki). $0.25 \%$ trypsin- $0.02 \%$ EDTA in Hank's balanced salt solution (59428C, Sigma) was used to remove cells that grew as an adherent monolayer at the bottom of the flask. Subcultures were normally established twice per week at a ratio of 1:2 with L-15 medium renewal.

\subsubsection{Gill cells exposure to K. selliformis}

The cytotoxicity assay was carried out using conventional multiwell microplates according to Dorantes-Aranda et al. (2011). K. selliformis cultures (CREAN_KSO2 strain) under different temperature (12, 15 and $18^{\circ} \mathrm{C}$ ) and salinity $(25,30$ and 35$)$ treatments were performed as in section 2.9. Cultures with confluent gill cells were trypsinized for detachment, counted using a haemocytometer and adjusted to a concentration of $2 \times 10^{5}$ cells $\mathrm{mL}^{-1}$. Subsequently, gill cells were seeded in quadruplicate in 96-well flat bottom microplates (3860-096, Iwaki, Japan), using a volume of $100 \mu \mathrm{L}$ per well. After $48 \mathrm{~h}$ at $17^{\circ} \mathrm{C}$ in the dark for gill cell attachment, L-15 medium was discarded, the cells rinsed with PBS and exposed to $100 \mu \mathrm{L}$ the experimental dinoflagellate treatments. Supernatant and lysed cells treatments were prepared from $K$. selliformis cultures in the exponential growth phase at 1000 cell 


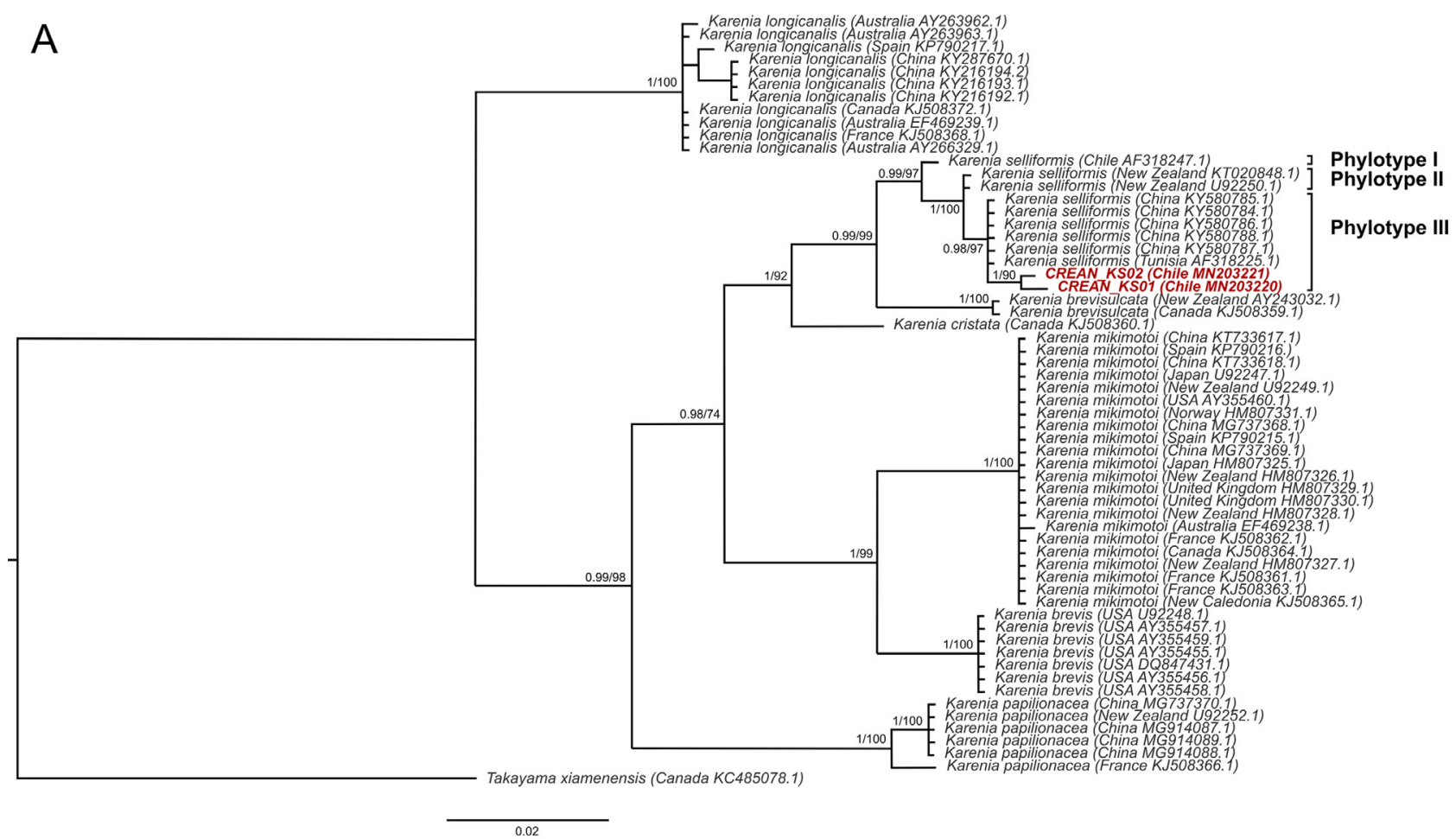

B

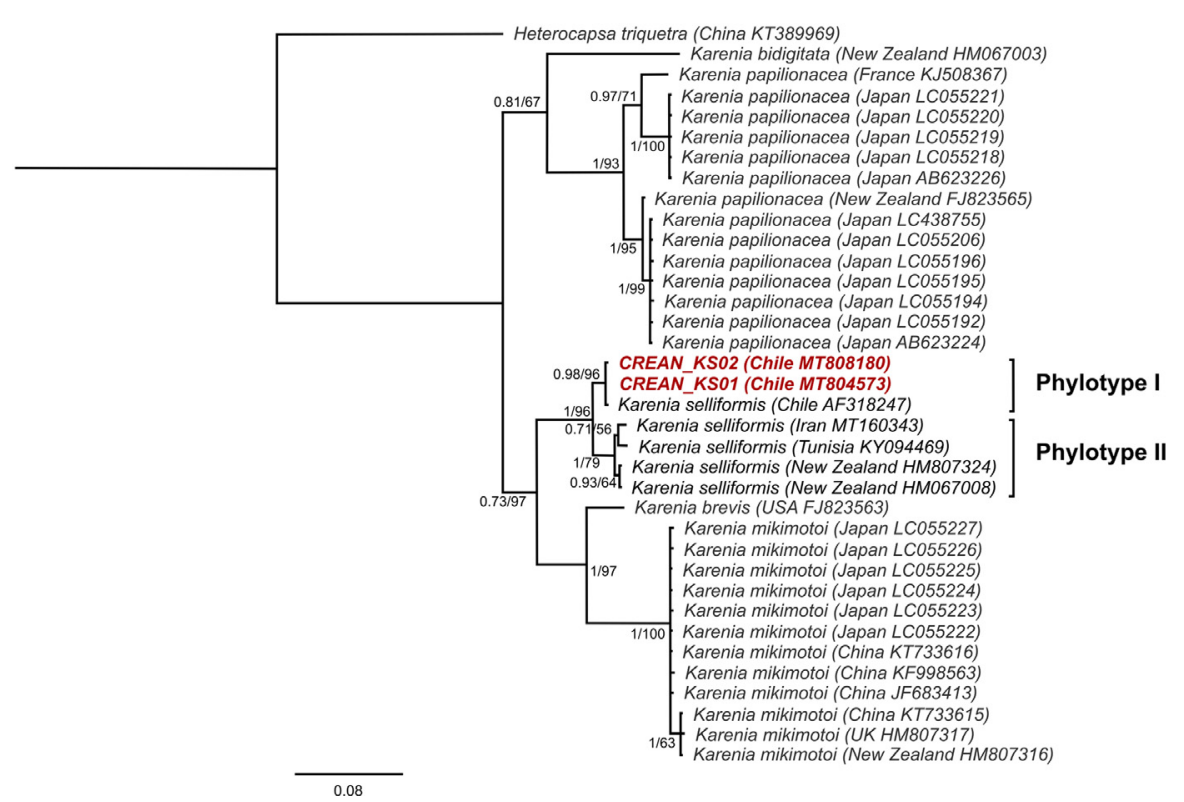

Fig. 2. Phylogeny of the (A) large subunit (LSU rDNA) and (B) Internal Transcriber Spacer (ITS1 + 5.8s + ITS2) sequences of Karenia selliformis strains and related species. Bayesian posterior probability values are shown with bootstrap values of maximum-likelihood (ML) analysis at each branching position. In red are the Chilean CREAN strains obtained in this study. Scale bar indicates the number of changes per site.

$\mathrm{mL}^{-1}$. The supernatant suspension was prepared by centrifugation of cultures for $5 \mathrm{~min}$ at $3500 \mathrm{rpm}$ and then diluted as needed. The lysed cell suspension was prepared by sonication of diluted samples for 10 min at an amplitude of $10 \mu \mathrm{m}$ peak to peak at $17^{\circ} \mathrm{C}$ and filtered using a syringe with a nylon filter $(0.22 \mu \mathrm{m})$. The exposure of $K$. selliformis intra- and extracellular compounds was carried out for $2 \mathrm{~h}$ at $17^{\circ} \mathrm{C}$ in the dark. Viability was assessed as in Section 2.8.4.

\subsubsection{Gill cells exposure to gymnodimine}

A pure standard of gymnodimine A (NRC CRM-GYM-b) dissolved in
$\mathrm{MeOH}$ at $4.93 \mu \mathrm{M}$, was obtained from the National Research Council (Halifax, NS, Canada). The gill cells were seeded and treated as specified in Section 2.8.2. The stock solution of GYM A with a concentration of $2.5 \mu \mathrm{g} \mathrm{mL}^{-1}$ was diluted in L15/ex $9.8 \%$ salinity on a logarithmic scale to seven different concentrations ranging from 0.22 to $2.2 \times 10^{5}$, equivalent to 0.01 to 10,000 cells $\mathrm{mL}^{-1}$ according to Medhioub et al. (2009), respectively. Viability of the cells was assessed as in Section 2.8.4., in dark conditions. 
Table 2

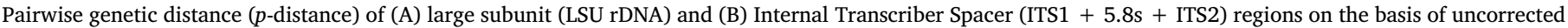
genetic distance data among groups/sequence and within groups of $K$. selliformis.

(A) ID $\quad$ Groups/sequence (sample number) Genetic distance ( \pm SD)

1

2

3

\begin{tabular}{|c|c|c|c|c|c|}
\hline 1 & This study $(\mathrm{n}=2)$ & 0.005 & & & \\
\hline 2 & CH $1999(n=1)$ & $0.017(0.001)$ & nd & & \\
\hline 3 & $\mathrm{TN}+\mathrm{CN}(\mathrm{n}=6)$ & $0.008(0.001)$ & $0.011(0.000)$ & $0.002(0.000)$ & \\
\hline 4 & $\mathrm{NZ}(\mathrm{n}=2)$ & $0.011(0.001)$ & $0.008(0.000)$ & $0.005(0.000)$ & 0.002 \\
\hline
\end{tabular}

(B) ID Groups/sequence (sample number) Genetic distance $( \pm$ SD)

1

2

4

5

This study $(\mathrm{n}=2)$

CH $1999(\mathrm{n}=1)$

$\mathrm{TN}(\mathrm{n}=1)$

IR $(\mathrm{n}=1)$

$\mathrm{NZ}(\mathrm{n}=2)$

$0.002(0.001)$

$0.036(0.000)$

$0.035(0.000)$

$0.031(0.000)$

nd

0.036 nd

$0.035 \quad 0.012 \quad$ nd

$\begin{array}{llll}0.031(0.000) & 0.015(0.000) & 0.014(0.000) & 0.002\end{array}$

Abbreviations: ${ }^{\mathrm{a}} \mathrm{CH}$, Chile; ${ }^{\mathrm{b}} \mathrm{TN}$, Tunisia, ${ }^{\mathrm{c}} \mathrm{CN}$, China; ${ }^{\mathrm{d}} \mathrm{IR}$, Iran; ${ }^{\mathrm{e}} \mathrm{NZ}$, New Zealand; nd, no data.

\subsubsection{Gill cell viability assay}

Gill cell viability was determined using L-15/ex medium, a modified version of the L-15 medium, containing $5 \%$ of the indicator dye alamarBlue (DAL1025, Invitrogen) (Pagé et al., 1993). The medium was added to all cell-seeded wells and incubated for $2 \mathrm{~h}$ in the dark (Dayeh et al., 2005). Immediately after exposure, the medium was discarded and cells were rinsed with phosphate buffer saline (PBS). Using a microplate reader (FLUOstar Omega, BMG Labtech 415-2871) the fluorescence of alamarBlue was detected with excitation and emission filters of 540 and $590 \mathrm{~nm}$, respectively. The viability of gill cells was expressed as response percentage of the treatments relative to the controls (\% of control).

\subsection{K. selliformis growth under different temperature and salinity}

The $K$. selliformis (CREAN_KSO2 strain) experiments were carried out in triplicate using sterile flasks, each containing $45 \mathrm{~mL}$ of L1 culture medium inoculated with 300 cells $\mathrm{mL}^{-1}$. The growth rate and culture yield were studied using a crossed factorial design with 16 different conditions, obtained from combining four temperatures $(9,12,15$ and $18^{\circ} \mathrm{C}$ ) and four salinities (20, 25, 30 and 35). To prevent alterations on the physiological response of the inoculum due to changes in temperature and salinity, the cultures were pre-acclimated to the desired experimental conditions via stepwise transfer over a defined period ( $>20$ days). The experiment was carried out for 29 days with samples taken every $5-7$ days. Cell density was determined immediately after sampling, based on buffered Lugol's fixed cells quantified under an inverted light microscope (MoticAE31E) using a Sedgewick-Rafter chamber. In every sampling date, the mean cell number obtained from the three replicates was used to calculate the growth rate $\mu\left(\mathrm{d}^{-1}\right)$ :

$\mu=\frac{\ln \left(c_{1} / c_{0}\right)}{t_{1}-t_{0}}$

were $\mathrm{c}_{o}$ and $\mathrm{c}_{1}$ are the cell densities (cell $\mathrm{mL}^{-1}$ ) at the beginning $\left(\mathrm{t}_{0}\right)$ and end $\left(t_{1}\right)$ of the incubation period (days), respectively.

\subsection{Statistical analysis}

To explore the effect of environmental variables on growth and ichthyotoxic potency of $K$. selliformis, analysis of variance (ANOVA) from simple linear regression models on maximum cell density, specific growth rate $(\mu)$ and gill cell viability against gymnodimine A and intraand extracellular $K$. selliformis compounds was performed. Normality and homogeneity of variances were assessed by the KolmogorovSmirnov method and Levene's test. A post hoc analysis using a Tukey HSD test was performed to determine differences among treatments. The null hypothesis (no difference in responses) was rejected in all statistical analyses if the respective $p$-value was $<0.05$. These analyses were performed using the software $\mathrm{R}$ v. 3.0.1 (Ihaka and Gentleman, 1996).

\section{Results}

\subsection{Phylogeny}

Both Maximum Likelihood and Bayesian phylogenetic analysis of the LSU D1-D2 region showed that the CREAN_KS01, CREAN_KSO2 sequences aggregated in a monophyletic clade that comprised only Karenia selliformis sequences, strongly supported by $97 \%$ bootstrap and 0.99 probability values (Fig. 2A). Within this clade, three nested clades were recognized with 0.98 to 1 probability and 90 to $100 \%$ bootstrap. The first clade separated Chilean CH 1999 strain from the Chinese (CN), Tunisian (TN), New Zealand (NZ) and the CREAN sequences in this study. The next nested clade showed that sequences from NZ diverged from the CN/TN and our CREAN sequences, supported by 1 probability and $100 \%$ bootstrap. The final nested clade comprised an aggregation of the CN/TN and our CREAN sequences. The genetic distances obtained from the LSU phylogenetic analysis ranged from 0.002 to 0.017 (Table 2A). The ITS phylogenetic analysis showed that the Chilean_2018 strains are represented in a monophyletic clade of $K$. selliformis strains (Fig. 2B). Within this clade, two statically well-supported nested clades were identified. The first clade grouped the two CREAN sequences isolated in 2018 with the Chilean $\mathrm{CH}_{-} 1999$ strain with $96 \%$ bootstrap and 0.98 posterior probability. The second clade comprised an aggregation of sequences from Iran (IR), Tunisia and New Zealand (Fig. 2B), supported by $79 \%$ bootstrap and 1 posterior probability. The genetic distances obtained from the ITS phylogenetic analysis ranged from 0.002 to 0.036 (Table 2B).

\subsection{Morphology}

Cells of the Chilean K. selliformis (CREAN_KS02 strain) measured 25$30 \mu \mathrm{m}$ in length, $20-25 \mu \mathrm{m}$ transdiameter and $18-22 \mu \mathrm{m}$ in thickness. Cells were light yellow-green with several peripherical chloroplasts. The nucleus was oblong and occupied most of the hyposome in a horizontal position. The episome was conical to hemispherical. The cingulum was descending and displaced by $1 \mathrm{x}$ the cingular width. The hyposome was larger than the episome, mostly rounded and with a negligible antapical concavity. A straight apical groove (ag) originated from the sulcal extension (se), which was of the open type sensu Haywood et al. (2004), and continued for a short distance on the dorsal side of the episome. Pores on the left lateral side of the hyposome were absent (Fig. 3). 

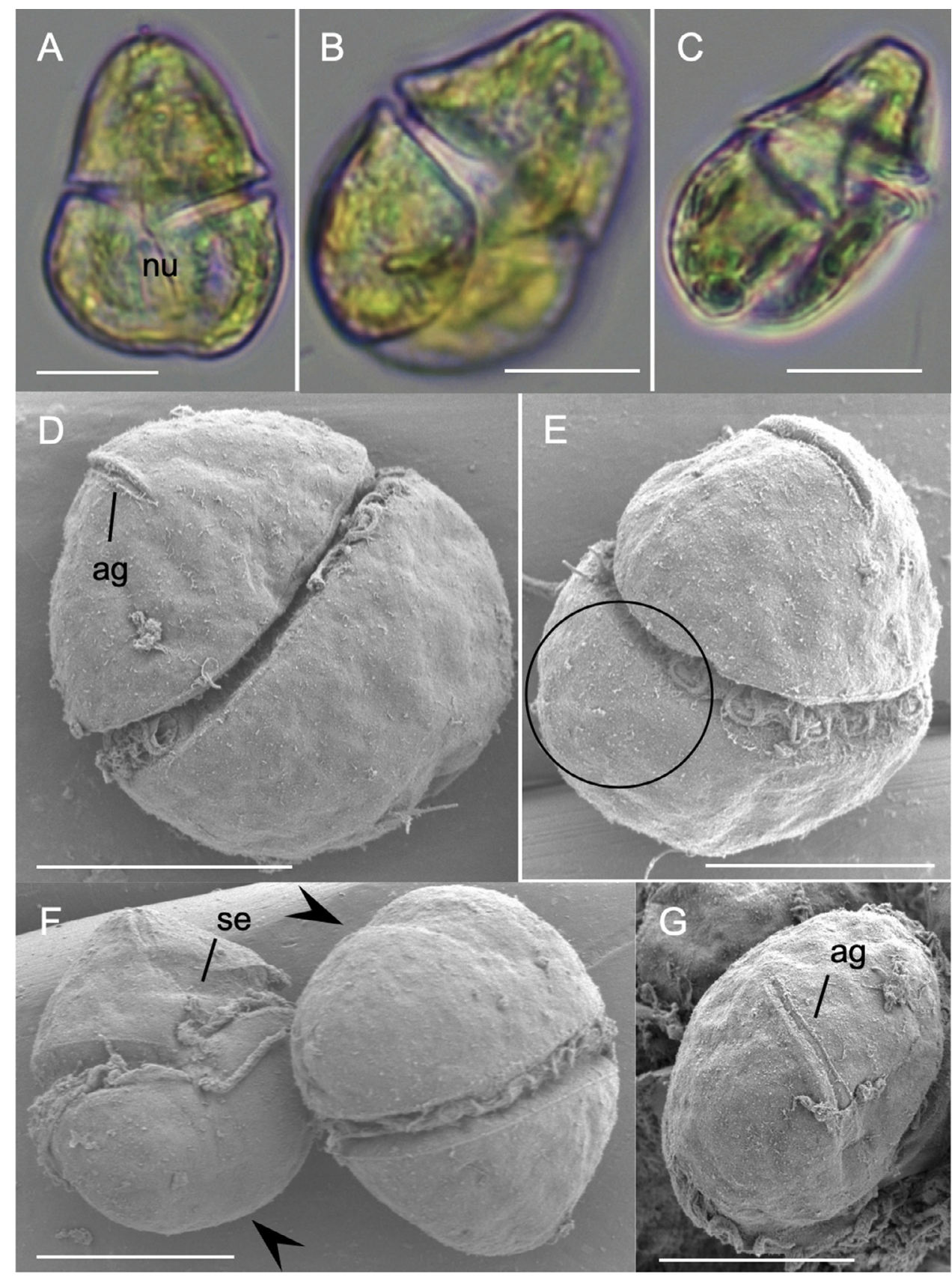

Fig. 3. Light (A-C) and scanning electron (D-G) micrographs of Karenia selliformis from Chile (CREAN_KSO2). (A) Dorsal view revealing horizontal elongate nucleus (nu) in the hyposome, (B) lateral view showing negligible dorso-ventral compression, (D) dorsal view showing the dorsal end of the apical groove (ag), (E) lateral view showing the absence of lateral pores (open circle), (F) ventral view showing the sulcal extension (se), and dorsal/ventral views showing a rounded hyposome with negligible concavity (arrows), (G) apical view showing the straight apical groove (ag). Scale bars: $10 \mu \mathrm{m}$.

\subsection{Pigment profile}

HPLC pigment analysis of an autotrophically grown culture of $K$. selliformis (CREAN_KS02) grown under at $100 \mu \mathrm{mol}$ photon $\mathrm{m}^{-2} \mathrm{~s}^{-1}$ light showed chlorophyll $a$ as the major pigment with chlorophyll $c_{2}$ and $c_{3}$ as accessory chlorophyll pigments (Fig. 4). Diadinoxanthin was the most abundant carotenoid followed by $19^{\prime}$-hexanoyl-oxyfucoxanthin, fucoxanthin, diatoxanthin, 19'-hexanoyloxy-4-ketofucoxanthin, 19 '-butanoyl-oxyfucoxanthin, zeaxanthin and carotene- $\beta$. The carotenoid biomarker 19' -hexanoyloxyparacentrone 3-acetate (gyroxanthin-diester) was also detected. The pigment composition of the Chilean KS_02 strain was similar to that described for $K$. selliformis strains from New Zealand, Tunisia and Chile (sampled in 1999), except for the minor presence of diadinoxanthin in the latter (Table 3).

\subsection{Toxin analysis}

None of the currently reported gymnodimines (Table 1) were detected in the two Chilean_2018 K. selliformis strains. The detection limit of GYM A was $0.025 \mathrm{fg}^{-}$cell ${ }^{-1}$ in strain KS_01 and $0.042 \mathrm{fg} \mathrm{cell}^{-1}$ in strain KS_02. Also, the analysis for brevetoxins did not result in any detectable levels of the screened variants (Table 1). Limits of detection (LOD) were determined as $0.59 \mathrm{fg} \mathrm{cell}^{-1}(\mathrm{PbTx}-2), 0.61 \mathrm{fg} \mathrm{cell}^{-1}$ (PbTx-3), $2.64 \mathrm{fg} \mathrm{cell}^{-1}$ (PbTx-6) and $5.25 \mathrm{fg} \mathrm{cell}^{-1}$ (PbTx-9) for strain KS01 and as $0.98 \mathrm{fg}^{-1 l^{-1}}$ (PbTx-2), $1.01 \mathrm{fg}$ cell $^{-1}$ (PbTx-3), $2.64 \mathrm{fg}$ cell $^{-1}$ (PbTx-6) and 5.25 fg cell $^{-1}\left(\mathrm{PbTx}_{-} 9\right)$ for strain KS02. However, 


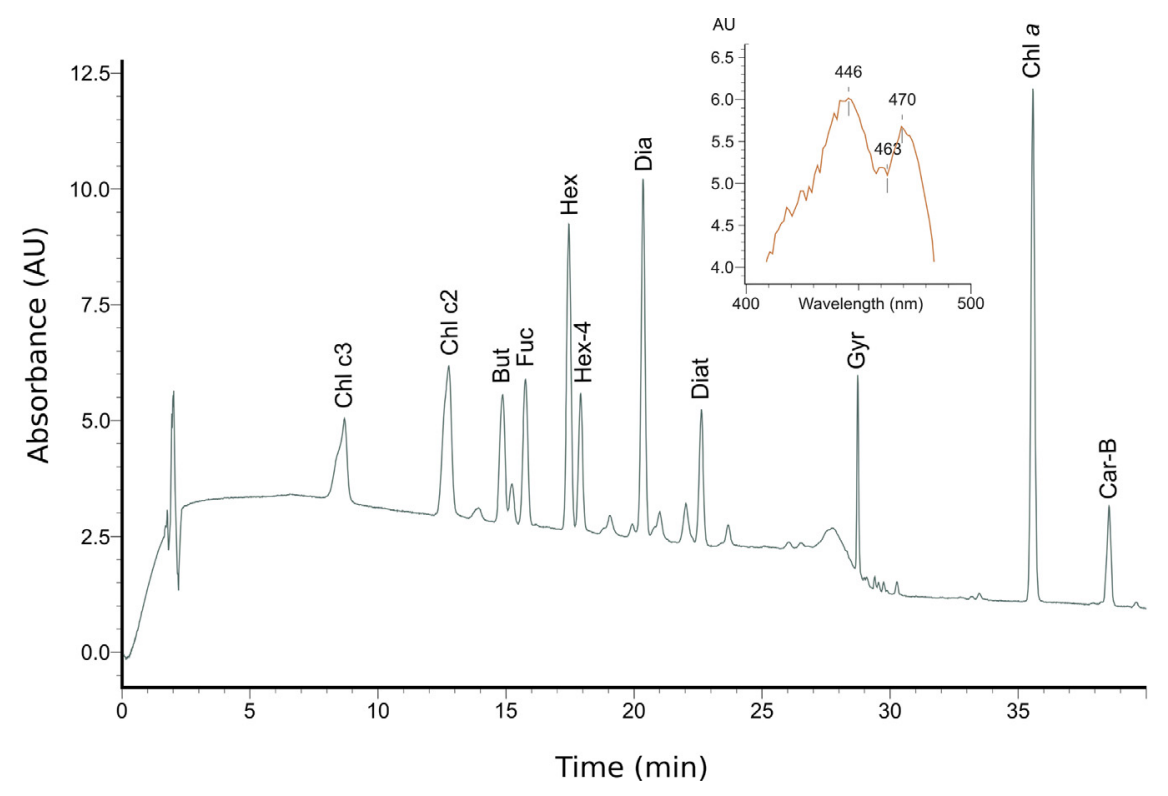

Fig. 4. HPLC profile of chloroplast pigments of the Chilean $K$. selliformis showing peaks of Chl $c_{2}, c_{3}$ (chlorophyll $c_{2}$, $c_{3}$ ), But (19'-butanoyl-oxyfucoxanthin), Fuc (fucoxanthin), Hex (19'-hexanoyl-oxyfucoxanthin), Pra (prasinoxanthin), Dia (diadinoxanthin), Diat (diatoxanthin), Gyr (gyroxanthin-diester), Chl a (chlorophyll $a$ ) and Car-B (carotene- $\beta$ ). Retention time in min on the $x$-axis and absorbance unit (AU) at $446 \mathrm{~nm}$ on the $y$-axis. Insert (orange curve) shows the absorbance spectrum of gyroxanthinediester.

Table 3

Pigment composition of Karenia selliformis from Chile (CL), New Zealand (NZ) and Tunisia (TN) as reported in literature and in this study.

\begin{tabular}{|c|c|c|c|c|c|c|c|c|c|c|c|c|c|c|}
\hline Strain/year & Country & Fuc & Hex & Hex-4 & But & Dia & Diat & Gyr & Zea & Per & Chl- $a$ & Chl-c2 & Chl-c3 & Reference \\
\hline N.D/1999 & Chile & & t & $+t$ & t & t & - & & - & - & & $\dagger$ & $t$ & Carreto et al., (2001) \\
\hline GM94GAB/1994 & Tunisia & $+t$ & $t$ & $t$ & $\dot{t}$ & $+t$ & - & - & - & - & & $+t$ & $\dot{t}$ & Hansen et al., (2004) \\
\hline N.D/N.D (\#) & New Zealand & & $t+$ & & $t$ & $t$ & * & & - & - & & & & Chang et al., (2013) \\
\hline
\end{tabular}

Pigment abbreviations: Fuc, fucoxanthin; Hex, 19' -hexanoyl-oxyfucoxanthin; Hex-4, 19'hexanoyloxy-4-ketofucoxanthin; But, 19' -butanoyl-oxyfucoxanthin; Dia, diadinoxanthin; Diat, diatoxanthin; Gyr, gyroxanthin-diester; Zea, zeaxanthin, Per, peridinin; Chl-a, chlorophyll-a; Chl-c2, chlorophyll-c2 and Chl-c3, chlorophyll-c3. (Note: ' + + +'=most abundant; ' + +'=moderate; '+' = minor; '“’’=trace amount; ' $'$ '= not detected; ' '= not reported. (\#) reported by Haywood (2001).

two peaks in the ion trace of the mass transition of brevenal $(\mathrm{m} / \mathrm{z}$ $657.4>639.4$ ) appeared at 3.39 and $3.61 \mathrm{~min}$. This prompted the record of collision induced dissociation (CID) spectra of these compounds, which clearly showed that both compounds were not identical with brevenal as the CID spectra of both compounds were distinct from the spectrum of brevenal (Fig. 5). These results indicate that both Chilean $K$. selliformis strains did not produce any known variants of gymnodimines and brevetoxins.

\subsection{Production of superoxide anion $\left(\mathrm{O}_{2}^{-}\right)$and fatty acid composition}

The fatty acid profile of the CREAN_KSO2 strain was dominated by saturated fatty acid (SFA) followed by polyunsaturated fatty acid (PUFA) and with only low levels of monounsaturated fatty acid (MUFA). The main fatty acids in decreasing order of abundance were

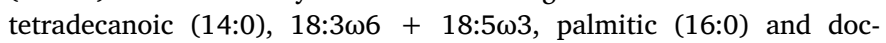

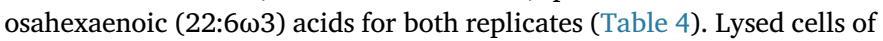
K. selliformis KS_02 showed higher rates of superoxide anion production $\left(0.86 \pm 0.53 \mathrm{pmol} \mathrm{O}_{2}^{-}\right.$cell $\left.^{-1} \mathrm{~h}^{-1}\right)$ compared to intact cells $\left(0.31 \pm 0.46 \mathrm{pmol} \mathrm{O}_{2}^{-}\right.$cell $^{-1} \mathrm{~h}^{-1}$ ) (Table 5).

\subsection{Cytotoxicity}

All treatments were highly toxic reducing gill cell viability down to between $28.3 \pm 0.47$ and $44.7 \pm 2.41 \%$ of controls (Fig. 6A). Lower salinity significantly increased cytotoxic potency of the KS_02 cultures (ANOVA, $\mathrm{df}=2, p<0.001$ ). Supernatant was slightly more toxic than lysed cell treatments but only at 35 salinity. Temperature did not affect significantly the cytotoxic potency of the cultures, except for the treatment at $12^{\circ} \mathrm{C}$ and 30 salinity (ANOVA, $\mathrm{df}=2, p<0.05$ ). A gymnodimine standard did not reduce gill cell viability at any of the seven concentrations tested (Fig. 6B).

\subsection{Effect of temperature and salinity on $K$. selliformis cell growth}

The response of $K$. selliformis CREAN_KS02 to changes in temperature and salinity was significantly different in terms of maximum cell biomass and specific growth rate $\mu$ (ANOVA, $\mathrm{p}<0.05$, Fig. 7). The $\mu_{\max }$ of $0.41 \pm 0.03 \mathrm{~d}^{-1}$ was reached at salinity $30 / 18^{\circ} \mathrm{C}$ and the lowest growth rate of $0.04 \pm 0.2 \mathrm{~d}^{-1}$ at salinity $20 / 9^{\circ} \mathrm{C}$ (Fig. 7A). The highest maximum cell density at stationary growth phase among all the factorial treatments was obtained at a salinity/temperature combination of $30 / 15^{\circ} \mathrm{C}\left(11,800 \pm 904\right.$ cells $\left.\mathrm{mL}^{-1}\right)$ and minimum cell density at 20/ $9^{\circ} \mathrm{C}\left(98 \pm 21\right.$ cells $\left.\mathrm{mL}^{-1}\right)$ (Fig. 7B).

\section{Discussion}

The present work investigated worldwide isolates of the cosmopolitan dinoflagellate complex of Karenia selliformis with regard to genetic and morphological properties and physiological characteristics of a new Chilean phylotype. We also newly report the occurrence of a nongymnodimine producing but highly cytotoxic phylotype.

\subsection{Comparative molecular phylogeny and morphology}

The phylogenetic reconstruction performed in this study, based on a set of large sub-unit (LSU) and Internal Transcriber Spacer (ITS) ribosomal nucleotide sequences, shows evidence for the aggregation of the Chilean_2018 strains within a well-supported monophyletic $K$. selliformis clade (Fig. 1). Among worldwide available $K$. selliformis sequences, divergence values up to 0.017 in LSU rDNA D1-D2 region and 0.036 in ITS region point to phylotype segregation in $K$. selliformis 


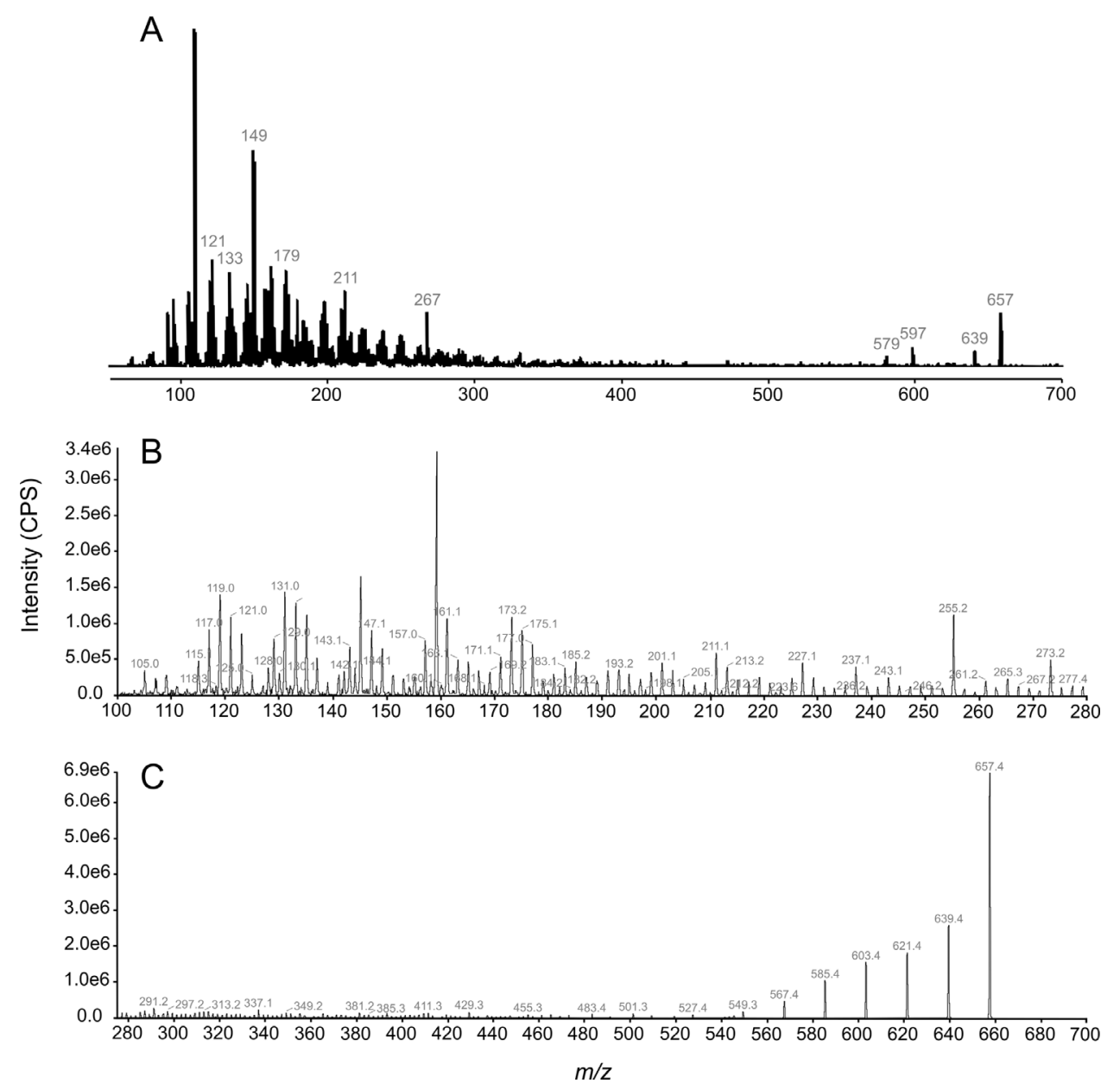

Fig. 5. Collision induced dissociation (CID) spectrum of A) the compound at 3.39 min of strain CREAN_KS02 (grown at $15{ }^{\circ} \mathrm{C}$, seawater at 35 in salinity and at 100 $\mu \mathrm{mol}$ photon $\mathrm{m}^{-2} \mathrm{~s}^{-1}$ under a 12:12 h light:dark cycle) isobaric with brevenal ( $\left.\mathrm{m} / \mathrm{z} 657.4\right)$ and B-C) CID spectrum of brevenal.

(Table 2). These results are in line with divergence values between $0.010-0.019$ previously used for the description of Karenia papilionacea phylotypes (Yamaguchi et al., 2016) and well supported by the use of two sets of data sequences (Al-Kandari et al., 2011). Interestingly, pairwise genetic distances between the Chilean_2018 sequences and the single sequence obtained from the 1999 outbreak (CH_1999) showed the highest values in LSU rDNA D1-D2 region (0.017) compared to the ITS region (0.002) (See Tables 2A and 2B for genetic divergence values among phylotypes). Based on LSU rDNA sequence data only, these results place the Chilean $\mathrm{CH}_{-} 1999$ sequence at the base of the $\mathrm{K}$. selliformis clade with the New Zealand, Chinese, Tunisian and Chilean_2018 groups deriving from it, suggesting the existence of at least three different phylotypes (=ribotypes): 1 ) the Chilean sequence isolated in 1999 (CH_1999) (Phylotype I); 2) NZ sequences (Phylotype II); and 3) CN/TN plus the Chilean 2018 sequences (this study) (Phylotype III) (Fig. 2A). By contrast, genetic distances based on available K. selliformis ITS sequence data revealed the existence of two phylotypes: phylotype I with the Chilean sequences (1999 and 2018) placed at the base of the clade, and phylotype II comprised of Tunisian, Iranian and New Zealand groups (Fig. 2B). For the Chilean coast, this study shows the presence of a unique $K$. selliformis phylotype based on ITS data and/or the potential occurrence of at least two K. selliformis phylotypes (I and III) based on LSU rDNA sequence data (CH_1999 and Chilean_2018). The discrepancy regarding the number of phylotypes discriminated by both LSU and ITS phylogenetic analyses relates to the high number of nucleotide substitutions shown by the CH_1999 in the LSU rDNA region. This fact might be due to PCR or sequencing artifacts since the CH_1999 sequence derives from a single cell extraction from a sample fixed with Lugol. Re-sequencing of aberrant divergent sequences can sometimes erase previously reported nucleotide substitutions (Al Kandary et al., 2011), but this strain unfortunately is no longer available. Further effort is required to screen more isolates from other locations, specially from Kuwait and Mexico where $K$. selliformis has only been described morphologically (Steidinger et al., 2008b).

The $K$. selliformis phylotypes share morphological characteristics as presented in the type description by Haywood et al., (2004): 1) Cell sizes range from $20-30 \mu \mathrm{m}$ long and 16-30 $\mu \mathrm{m}$ transdiameter; 2) Yellowgreen chloroplasts with pyrenoids; 3) Episome usually smaller than hyposome; 4) Oblong nucleus positioned horizontally in the hypotheca; 5) Descending cingulum displaced by $1-1.5 x$ the cingular width; and 6) Straight apical groove that descends about $1 / 5$ of the cell length and joins the right sulcal margin and with the left sulcal intrusion usually narrow but open onto the epitheca (Haywood et al., 2004; Hansen et al., 2004; Steidinger et al., 2008b; this study). Morphological differences among the three phylotypes related to the dorsal-ventral compression, the hyposome shape and the presence or absence of pores on the left hyposome lobe. Neither Chilean (CREAN_KS02 strain) or Tunisian cells (phylotype III) are dorso-ventrally compressed as described by Haywood et al., (2004) for the New Zealand strain (phylotype II). The hyposome excavation in the Chilean CREAN_KS02 strain and Tunisian strains is much shallower than in strains from New Zealand and from the Gulf of Mexico. This feature is notably pronounced in the CREAN_KS02 strain where the hyposome is rounded with negligible concavity (Fig. 3F). K. selliformis from New Zealand and Gulf of Mexico has been reported to possess a single pore on the left lateral side of the hyposome (Haywood et al., 2004; Steidinger et al., 
Table 4

Fatty acid composition of the Patagonian $K$. selliformis (as \% of total fatty acids).

$\begin{array}{ll}\text { Fatty acid } & \text { Samples } \\ & \text { A }\end{array}$

\begin{tabular}{|c|c|c|c|c|c|c|}
\hline \multicolumn{7}{|l|}{ SFA } \\
\hline $14: 0$ & 20.2 & \pm & 1.4 & 21.1 & \pm & 0.2 \\
\hline $15: 0$ & 0.8 & \pm & 0.0 & 0.4 & \pm & 0.0 \\
\hline 16:0 PA & 16.3 & \pm & 0.7 & 16.2 & \pm & 0.1 \\
\hline $17: 0$ & 0.3 & \pm & 0.0 & 0.2 & \pm & 0.0 \\
\hline 18:0 & 3.9 & \pm & 0.3 & 3.9 & \pm & 0.0 \\
\hline $20: 0$ & 0.8 & \pm & 0.0 & 0.8 & \pm & 0.0 \\
\hline $22: 0$ & 0.0 & \pm & 0.0 & 0.0 & \pm & 0.0 \\
\hline $24: 0$ & 0.1 & \pm & 0.0 & 0.1 & \pm & 0.0 \\
\hline \multicolumn{7}{|l|}{ MUFA } \\
\hline $14: 1$ & 0.3 & \pm & 0.0 & 0.3 & \pm & 0.0 \\
\hline $16: 1 \omega 9 c$ & 0.4 & \pm & 0.1 & 0.4 & \pm & 0.1 \\
\hline $16: 1 \omega 7 c$ & 8.0 & \pm & 0.2 & 8.2 & \pm & 0.1 \\
\hline $16: 1 \omega 7 \mathrm{t}$ & 0.0 & \pm & 0.0 & 0.0 & \pm & 0.0 \\
\hline $16: 1 \omega 5 c$ & 0.2 & \pm & 0.0 & 0.2 & \pm & 0.0 \\
\hline $16: 1 \omega 13 t$ & 0.6 & \pm & 0.0 & 0.6 & \pm & 0.0 \\
\hline $18: 1 \omega 9 c$ & 3.4 & \pm & 0.1 & 3.6 & \pm & 0.1 \\
\hline $18: 1 \omega 7 \mathrm{c}$ & 1.4 & \pm & 0.2 & 1.7 & \pm & 0.0 \\
\hline $18: 1 \omega 7 \mathrm{t}$ & 0.0 & \pm & 0.0 & 0.0 & \pm & 0.0 \\
\hline $18: 1 \omega 5 c$ & 0.0 & \pm & 0.0 & 0.0 & \pm & 0.0 \\
\hline $19: 1$ & 0.0 & \pm & 0.0 & 0.0 & \pm & 0.0 \\
\hline $20: 1 \omega 11 c$ & 0.1 & \pm & 0.0 & 0.1 & \pm & 0.0 \\
\hline $20: 1 \omega 9 c$ & 0.0 & \pm & 0.0 & 0.0 & \pm & 0.0 \\
\hline $20: 1 \omega 7 c$ & 0.6 & \pm & 0.0 & 0.4 & \pm & 0.2 \\
\hline $20: 1 \omega 5 c$ & 0.1 & \pm & 0.0 & 0.1 & \pm & 0.0 \\
\hline $22: 1 \omega 13 c$ & 0.0 & \pm & 0.0 & 0.0 & \pm & 0.0 \\
\hline $22: 1 \omega 11 c$ & 0.0 & \pm & 0.0 & 0.0 & \pm & 0.0 \\
\hline $22: 1 \omega 9 c$ & 0.0 & \pm & 0.0 & 0.0 & \pm & 0.0 \\
\hline $22: 1 \omega 7 \mathrm{c}$ & 0.0 & \pm & 0.0 & 0.0 & \pm & 0.0 \\
\hline $23: 1$ & 0.0 & \pm & 0.0 & 0.0 & \pm & 0.0 \\
\hline $24: 1 \omega 11 c$ & 0.0 & \pm & 0.0 & 0.0 & \pm & 0.0 \\
\hline $24: 1 \omega 9 c$ & 0.0 & \pm & 0.0 & 0.0 & \pm & 0.0 \\
\hline $24: 1 \omega 7 \mathrm{c}$ & 0.0 & \pm & 0.0 & 0.0 & \pm & 0.0 \\
\hline \multicolumn{7}{|l|}{ PUFA } \\
\hline $18: 3 \omega 6+18: 5 \omega 3$ & 18.9 & \pm & 0.6 & 18.4 & \pm & 0.2 \\
\hline $18: 4 \omega 3$ & 0.7 & \pm & 0.1 & 0.6 & \pm & 0.0 \\
\hline $18: 2 \omega 6$ & 3.4 & \pm & 0.2 & 3.2 & \pm & 0.0 \\
\hline $18: 3 \omega 3$ & 0.3 & \pm & 0.0 & 0.3 & \pm & 0.0 \\
\hline $20: 4 \omega 6$ & 0.6 & \pm & 0.0 & 0.5 & \pm & 0.0 \\
\hline $20: 5 \omega 3$ & 1.3 & \pm & 0.0 & 1.3 & \pm & 0.0 \\
\hline $20: 3$ & 0.1 & \pm & 0.0 & 0.1 & \pm & 0.0 \\
\hline $20: 3 \omega 6$ & 0.0 & \pm & 0.0 & 0.0 & \pm & 0.0 \\
\hline $21: 5 \omega 3$ & 0.1 & \pm & 0.1 & 0.0 & \pm & 0.0 \\
\hline $22: 5 \omega 6$ & 0.1 & \pm & 0.1 & 0.1 & \pm & 0.0 \\
\hline $22: 6 \omega 3$ DHA & 14.0 & \pm & 0.7 & 14.3 & \pm & 0.4 \\
\hline $22: 4 \omega 6$ & 0.1 & \pm & 0.0 & 0.1 & \pm & 0.0 \\
\hline $22: 5 \omega 3$ & 0.2 & \pm & 0.0 & 0.2 & \pm & 0.0 \\
\hline Sum SFA & 42.4 & & 2.6 & 42.7 & & 0.4 \\
\hline Sum MUFA & 15.3 & & 0.9 & 15.7 & & 0.6 \\
\hline Sum PUFA & 39.6 & & 1.8 & 39.1 & & 0.7 \\
\hline
\end{tabular}

Abbreviations: SFA, saturated fatty acids; MUFA, monounsaturated fatty acids; PUFA, polyunsaturated fatty acids; PA, palmitic acid (16:0); DHA, docosahex-

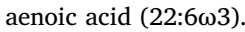

2008b). In contrast, Hansen et al., (2004) reported one to three lateral pores in Tunisian $K$. selliformis, while these pores were absent in our Chilean_2018 cells (Fig. 3E).

\subsection{Pigment composition in K. selliformis phylotypes}

In this study $K$. selliformis CREAN_KSO2 was found to possess 19'hexanoyl-oxyfucoxanthin as the primary carotenoid (acyl-oxyfucoxanthin-rich) with fucoxanthin as a minor pigment. This is similar to $K$. selliformis from New Zealand (Haywood, 2001) but differs from the Chilean 1999 bloom as well as Tunisian GM94GAB strains that contained fucoxanthin as the primary carotenoid (fucoxanthin-rich) (Carreto et al., 2001; Hansen et al., 2004) (Table 2). Plastids of dinoflagellates that possess fucoxanthin/ acyl-oxyfucoxanthin derivatives are thought to have derived from haptophyte or chrysophyte algae by means of a tertiary endosymbiosis (e.g., Tangen and Bjørnland, 1981; Ishida and Green, 2002; Takishita et al., 2004). 19'-hexanoyl-oxyfucoxanthin-rich New Zealand and Chilean Karenia selliformis thus may have haptophyte symbionts, while Chilean $\mathrm{CH}_{-} 1999$ and Tunisian strains rich in fucoxanthin might contain plastids similar to Pelagococcus subviridis (Chrysophyceae) as suggested for $K$. mikimotoi (Suzuki and Ishimaru, 1992). The Chilean CREAN_KS02 strain, in addition to acyl-oxyfucoxanthin derivatives, also produced the photoprotective xanthophyll cycle pigments diadinoxanthin and diatoxanthin. Diatoxanthin has only been reported for the New Zealand and Patagonian $K$. selliformis in trace amounts, respectively (Table 3). Diadinoxanthin can be transferred into diatoxanthin when exposed to high light stress (Lavaud et al., 2004) and incidence of these pigments is strongly dependent on light history.

All $K$. selliformis contained the carotenoid pigment gyroxanthindiester (Table 3). As originally described by Bjørnland et al., (2000), gyroxanthin-diester was proposed as a biomarker for several species of the Kareniaceae family (e.g., Karenia brevis and Karlodinium veneficum), However, this pigment has since been reported from pelagophytes (Pelagococcus subviridis and Aureococcus anophagefferens) and haptophytes (Emiliania huxleyi, Chrysochromulina leadbeateri, C. hirta and Imantonia rotunda) (Zapata, 2005). Hence, gyroxanthin-diester can no longer be used as an exclusive chemo-taxonomical character for Kareniacea detection except when in high biomass blooms and under near absence of pelagophytes and haptophytes.

\subsection{Toxicity of Patagonian K. selliformis}

Karenia species are well known for their production of a variety of potent phycotoxins that can kill fish and other marine fauna (Brand et al., 2012; Hallegraeff et al., 2017). Most of the toxic compounds produced by Karenia have not yet been fully characterized. Among the best-studied phycotoxins associated with Karenia are brevetoxins known to be produced by Karenia brevis and are causative of neurotoxic shellfish poisoning (NSP) mostly affecting the Gulf of Mexico. A less studied group of toxins linked with Karenia are gymnodimines. Gymnodimine A was first reported from Karenia selliformis in New Zealand (Seki et al., 1995) and later GYM B and C characterized from the same region (Miles et al., 2000, 2003). Also, a strain of $K$. selliformis isolated in the Mediterranean Sea (Tunisia) was proven to produce GYM A (Biré et al., 2002). Nonetheless in recent years several strains of the unrelated dinoflagellate species Alexandrium ostenfeldii from different geographic

Table 5

Production of superoxide radical $\mathrm{O}_{2}{ }^{-}$by the Chilean $\mathrm{K}$. selliformis under two conditions (whole and lysed cells). Superoxide from two strains of the raphidophyte Chattonella marina (Australia and Japan) was measured with comparative purposes.

\begin{tabular}{|c|c|c|c|c|c|c|c|c|}
\hline Species & Strain & Origin & Isolator & Original source & $\begin{array}{l}\mathrm{pmol} \mathrm{O}_{2}^{-} / \mathrm{ce} \\
\text { Whole cells }\end{array}$ & $\mathrm{SD}$ & Lysed cells & SD \\
\hline $\begin{array}{l}\text { Karenia selliformis } \\
\quad \text { (Chile) }\end{array}$ & CREAN_KSO2 & $\begin{array}{l}\text { Region de Aysen, } \\
\text { Chile }\end{array}$ & $\begin{array}{l}\text { J. I. Mardones (March, } \\
\text { 2018) }\end{array}$ & CREAN-IFOP, Chile & 0.3108 & 0.4674 & 0.8606 & 0.5351 \\
\hline Chattonella marina (Aus) & CMPL04 & $\begin{array}{l}\text { Port Lincoln, } \\
\text { Australia }\end{array}$ & M. de Salas (2001) & University of Tasmania, Australia & 0.7494 & 0.4380 & 2.5226 & 0.5331 \\
\hline Chattonella marina (Jap) & $\mathrm{N}-118$ & $\begin{array}{l}\text { Seto Inland Sea, } \\
\text { Japan }\end{array}$ & S. Yoshimatsu (1983) & $\begin{array}{l}\text { National Institute of Environmental } \\
\text { Studies, Japan }\end{array}$ & 2.0775 & 0.8797 & 2.3162 & 0.3145 \\
\hline
\end{tabular}



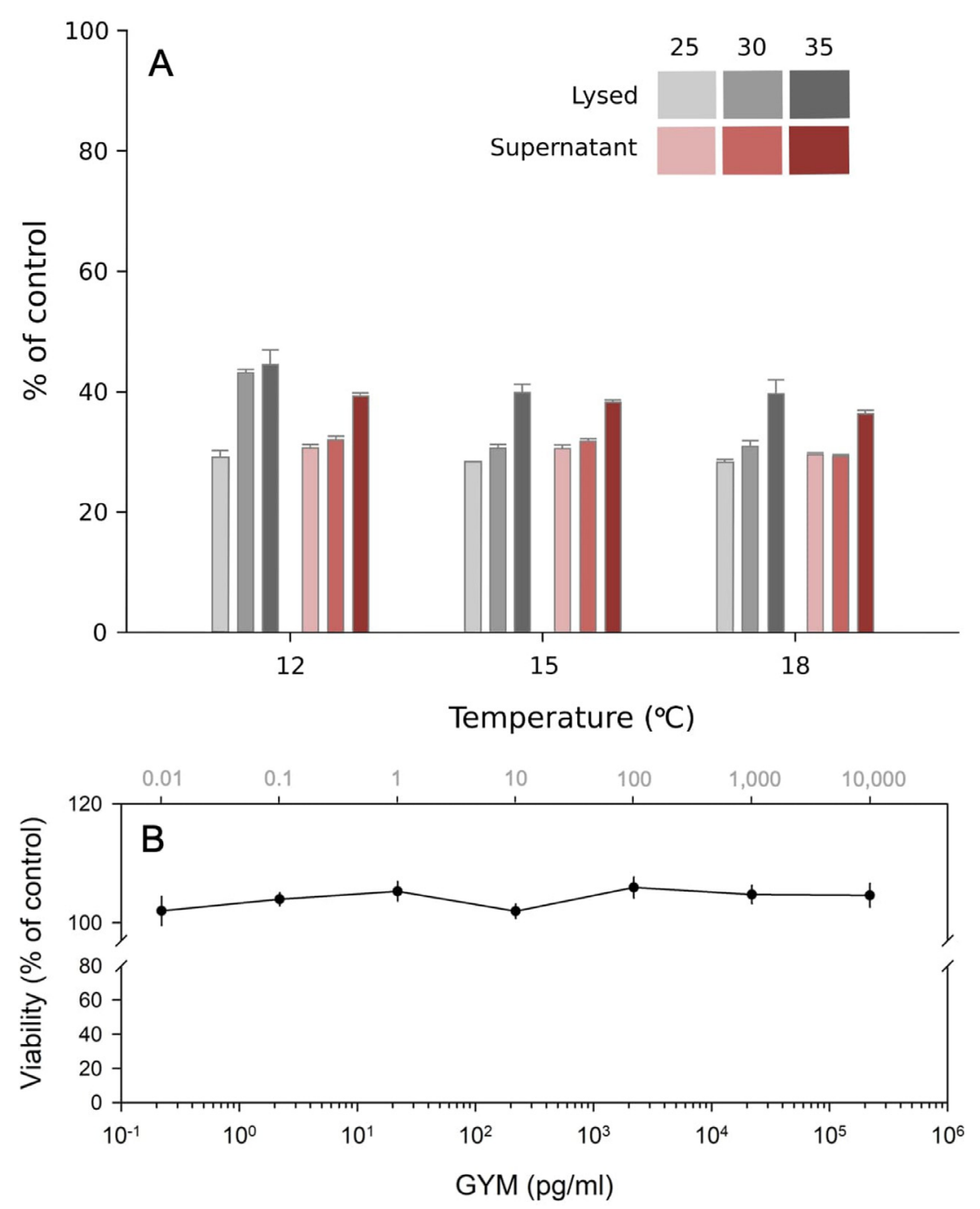

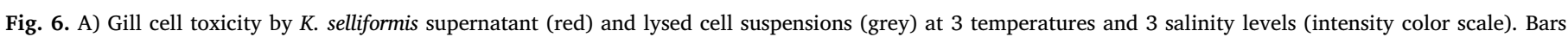

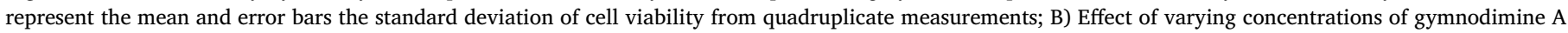

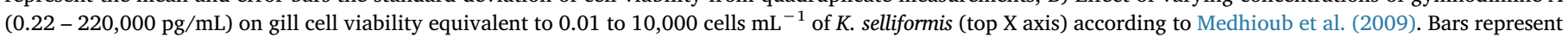
the mean and error bars the standard deviation of cell viability from quadruplicate measurements.

regions were also shown to produce several GYM variants, namely 12 methyl-gymnodimine A (Van Wagoner et al., 2011), GYM D (Harju et al., 2016), 12-methyl GYM B (Strangman et al., 2016), 16desmethyl GYM D and GYM E (Zurhelle et al., 2018). The least studied group of toxins associated with Karenia are gymnocins, which were found in Karenia mikimotoi (Satake et al., 2002; 2005). Furthermore, several Karenia species have been associated with severe fish kills (Hallegraeff et al., 2017), but the causative ichthyotoxins have not yet been reported in the scientific literature and are subject to future research. In order to characterize the new strains of $K$. selliformis we aimed to screen them for the presence of phycotoxins that have been associated with Karenia so far. Despite the fact that gymnocins were reported already in the last century there still are no available analytical standards and quantification methods for gymnocins. As analysis of gymnocins and ichthyotoxins was not possible due to the lack of available standards and methods, it was aimed to screen for brevetoxins and GYMs, which previously have been associated with the genus Karenia, but both toxin groups were not detected in the Chilean_2018 K. selliformis strains.

Interestingly, both strains contained two compounds with the same mass transition as brevenal, a brevetoxin related compound. Nevertheless, a comparison of the CID spectrum of brevenal, that hardly shows any other fragments than water losses from the pseudo-molecular ion, was clearly distinct from the CID spectra of these unknowns, but isobaric compounds (Fig. 5) and apparently are not related to the brevetoxin group. The same compound has recently been found in an extract of the unrelated raphidophyte Heterosigma akashiwo (GallardoRodríguez et al., 2020), which gives reason to assume that this compound may not be species-specific and may be found in several microalgal species. Since no brevenal CID spectrum has been published nor purified standard is commercially available, this observation may be helpful for chemical analysts in order to avoid possible misidentification of this unknown compound as brevenal.

The absence of GYM in the Chilean_2018 strains of $K$. selliformis represents the first record of non-GYM producing $K$. selliformis cultures and is in agreement with the failure to detect GYMs in field samples from the massive 2018 bloom in Patagonian fjords (IFOP, unpublished data). Nevertheless, Trefault et al., (2011) reported GYM A from water samples in low levels $\left(<2 \mathrm{pg} \mathrm{L}^{-1}\right)$ along a wide latitudinal transect along the Chilean coast between $45.1737^{\circ} \mathrm{S}$ (Puerto Aysén) and $39.5861^{\circ} \mathrm{S}$ (Temuco), which leaves open the question of the source organism(s) of GYM in Chilean waters. The detection of GYM in Chilean waters could also be related to the other known GYM producer, dinoflagellate Alexandrium ostenfeldii. Nevertheless, GYM A-producing A. 

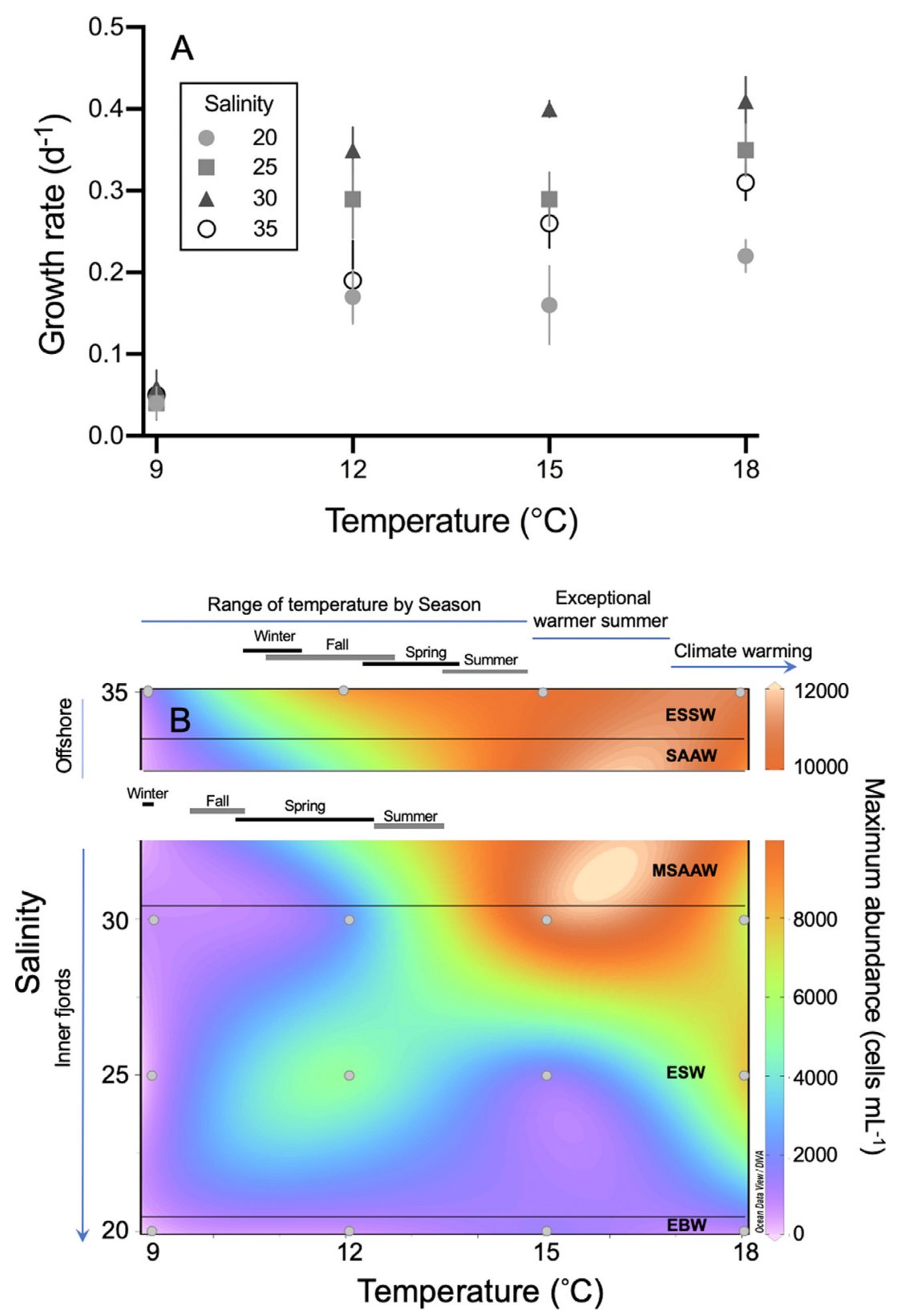

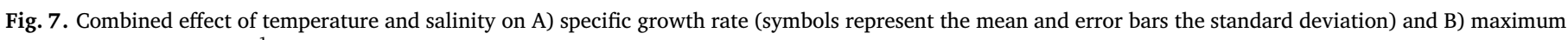

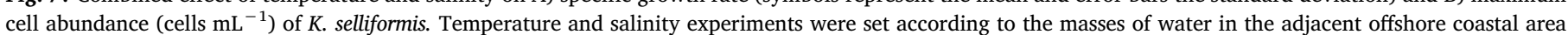

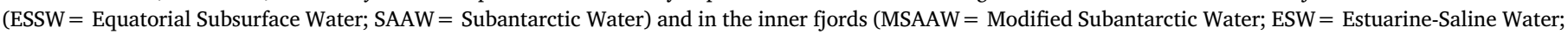
$\mathrm{EBW}=$ Estuarine-Brackish Water), and based on their expected fluctuations by season, exceptional warmer summers and potential climate warming.

ostenfeldii only have been reported from an enclosed estuary in the Netherlands until now (Martens et al., 2017). Furthermore, no GYM production has been reported from Chilean $A$. ostenfeldii cultures so far (Salgado et al., 2015), and the origin of GYMs in Chilean waters remains to be solved.

Karenia species have been shown to produce allelochemical compounds that suppress the growth of other algae species and/or cytotoxins that can disrupt cell membranes, apparently by altering osmotic balance and ion pumps (Kubanek et al., 2005; Prince et al., 2010). In this study, the Chilean $K$. selliformis CREAN_KSO2 was highly cytotoxic to the RTgill-W1 rainbow trout gill cell line under a wide range of temperature and salinity culture conditions (Fig. 6A). This cytotoxic effect cannot be attributed to neither GYMs nor brevetoxins as the Chilean_2018 K. selliformis strains do not produce them. In addition, in this study it was demonstrated for first time that purified GYM-A did not affect fish gill cell viability (Fig. 6B), which agrees with negligible hemolytic activity of GYM reported by Tatters et al., (2010). Similarly, phycotoxins such as Gymnocin A and B produced by K. mikimotoi are only weakly toxic to fish (Silke et al., 2005; Mardones et al., 2018). The massive fauna mortality observed in the Chilean coast in 2018 must therefore be related to different bioactive compounds other than GYMs nor brevetoxins if the bloom was dominated by $K$. selliformis.

Numerous investigations have shown that a variety of toxic sterols and polyunsaturated fatty acids (PUFAs) might be responsible for allelopathy and cytotoxicity in Karenia species (Arzul et al., 1995; Bodennec et al., 1995; Fossat et al., 1999; Sola et al., 1999; Gentien et al., 2007). For instance, Mooney et al., (2007) showed that $K$. longicanalis ( $=K$. umbella), K. papilionacea, K. mikimotoi and K. brevis all produce lipids, sterols and PUFAs that may act as cytotoxic compounds. The present study showed that the CREAN_KSO2 isolate produced high abundance of the fatty acids tetradecanoic (14:0), c-linolenic $(18: 3 \omega 6)+$ octadecapentaenoic (18:5 $\omega 3)$, palmitic (16:0) and 


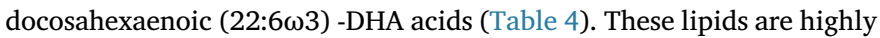
reactive and have been demonstrated to be cytotoxic to rainbow trout gill cells (Mooney et al., 2011; Dorantes-Aranda et al., 2015; Mardones et al., 2015). Toxicity of PUFAs can be enhanced by lipid peroxidation in the presence of reactive oxygen species (ROS) (Mooney et al., 2007). Measurements of ROS (as superoxide) in the CREAN_KSO2 strain demonstrated that this isolate is a low superoxide producer compared to the ichthyotoxic raphidophyte Chattonella marina from Australia and Japan (Table 5). Low production of superoxide by $K$. selliformis renders it improbable to attribute cytotoxicity exclusively to the PUFAs/ROS synergism, unless another source of ROS in the surrounding aquatic environment. The 2018 Kareniaceae bloom event was extremely toxic killing a wide variety of marine fauna, including cultured fish (salmo salar), sea urchins (i.e., Loxechinus albus; Arbacia dufresnii), octopus (i.e., Enteroctopus megalocyathus), sea stars (i.e., Henricia obesa; Meyenaster gelatinosus) and several species of bivalves (i.e., Mesodesma donacium; Protothaca thaca); thus, the involvement of other potent toxins must be pursued.

\subsection{Implications of K. selliformis cell growth for bloom dynamics in the Chilean Patagonia}

The toxic dinoflagellate Karenia has attracted considerable scientific attention in the Patagonian fjords due to sporadic massive mortality of fish and other marine life. However, there exist not enough data on its population dynamics or the processes leading to bloom formation. It has been observed that blooms in Chilean waters include several Karenia species (i.e., K. papilionacea, $K$. bicuneiformis; IFOP, unpublished data) but also species of other genera of the Kareniaceae family (e.g., Karlodinium; IFOP, unpublished data). This fact complicates the identification of the toxicity source since fauna mortality cannot always be attributed to any one specific toxin or species.

The Kareniaceae bloom in 2018 covered hundreds of kilometers in area. The answer to the fundamental question of how Karenia species can develop such a large biomass in a bloom is largely unknown. Most dinoflagellates such as Karenia replicate very slowly, less than once a day (Brand et al., 2012), which is a disadvantage to outcompete fast growing microalgae such as diatoms. However, dinoflagellates are active swimmers, which allow them to undergo diel vertical migrations to access to higher concentrations of nutrients below the pycnocline in stratified waters such as the Chilean fjords. The Chilean $K$. selliformis CREAN_KSO2 showed an optimal growth rate of $0.41 \pm 0.03 \mathrm{~d}^{-1}$ (Fig. 7A), which is in line with that reported for Tunisian $K$. selliformis GM94GAB strain $\left(0.34 \pm 0.14 \mathrm{~d}^{-1}\right)$ (Medhioub et al., 2009). Optimal growth obtained in bioassays was reached at high temperature $\left(18{ }^{\circ} \mathrm{C}\right)$ and salinity (30) with a maximum cell abundance of $11,800 \pm 904$ cells $\mathrm{mL}^{-1}$ (Fig. 7B). These results agree with local monitoring data that show Karenia blooms as an oceanic phenomenon occurring during the summer season (Clément et al., 2001; Carreto et al., 2001; Uribe and Ruiz, 2001).

Low tolerance to low salinity in estuarine masses of waters (EBW and ESW in Fig. 7B) would not allow $K$. selliformis cell division in overwintering populations but might be enhanced in open ocean waters (MSAAW and ESSW in Fig. 7B). Similar preference for high salinity has also been reported for $K$. brevis in the Gulf of Mexico, where blooms of this species are generally found in coastal waters but not estuaries (Magaña and Villareal, 2006). Sporadic blooms of $K$. brevis have occurred in estuaries during droughts when the salinity is higher in the estuary (Steidinger and Ingle, 1972; Landsberg and Steidinger, 1998). Exceptional climatic anomalies in the Patagonian fjords during the austral summer 2016 led to a massive bloom of the ichthyotoxic dictyochophyte Pseudochattonella verruculosa and the PST-producer dinoflagellate Alexandrium catenella (Trainer et al., 2019). High salinity within the fjords was claimed to be one of the main responsible drivers for high growth of $P$. verruculosa in that event (Mardones et al., 2019). This has implications for mitigation and management of potential $K$. selliformis blooms by the salmon industry, especially since blooms of Karenia has only been observed in oceanic coastal waters so far.

In conclusion, based on genetics, taxonomy and pigment composition of worldwide isolates, this study suggests that $K$. selliformis may constitute a "species complex", and comprises at least two phylotypes. The Chilean_2018 isolates represent the first non-gymnodimine producer $K$. selliformis strains maintained in culture. This result might stimulate debate about the ecological function of this phycotoxin in $K$. selliformis as well as leaves open the question regarding the source of GYMs in Chilean waters. The high cytotoxicity observed in the CREAN_KSO2 strain poses a major threat for the native marine fauna and local salmon industry, especially under a climate change scenario, due to its enhanced growth rates at high temperatures. Future research related to Chilean $K$. selliformis toxicity should focus on bio-guided fractionation for deeper insight into the two unknown brevenal closerelated compounds reported in this study and their relation with cytotoxicity. Further characterization of more Chilean $K$. selliformis isolates is needed in order to confirm the absence of GYMs.

\section{Declaration of Competing Interest}

The authors declare that they have no known competing financial interests or personal relationships that could have appeared to influence the work reported in this paper.

\section{Acknowledgements}

The authors thank Andrea Bourdelais, University of North Carolina Wilmington, for the provision of a CID spectrum of brevenal and colleagues from the CREAN laboratory for microalgae culture support. Funding was provided by the Instituto de Fomento Pesquero (IFOP) (Grants MR656-114, MR656-123, and CORFO 480-018).

\section{References}

Al-Kandari, M.A., Highfield, A.C., Hall, M.J., Hayes, P., Schroeder, D.C., 2011. Molecular tools separate harmful algal bloom species, Karenia mikimotoi, from different geographical regions into distinct sub-groups. Harmful Algae 10, 636-643.

Anisimova, M., Gascuel, O., 2006. Approximate likelihood-ratio test for branches: a fast, accurate, and powerful alternative. Syst. Biol. 55, 539-552.

Arzul, G., Gentien, P., Bodennec, G., Toularastel, F., Youenou, A., Crassous, M.P., 1995. Comparison of toxic effects in Gymnodinium $c f$. nagasakiense polyunsaturated fatty acids. In: Lassus, P., Arzul, G., Erard, E., Gentien, P., Marcaillou, C. (Eds.), Harmful Marine Algal Blooms. Intercept Ltd., Technique et Documentation, Lavoisler, pp. 395-400.

Biré, R., Krys, S., Fremy, J.M., Dragacci, S., Stirling, D., Kharrat, R., 2002. First evidence on occurrence of GYM in clams from Tunisia. J. Nat. Toxins 11, 269-275.

Bjørnland, T., Fiksdahl, A., Skjtne, T., Krane, J., Liaaen-Jensen, S., 2000. Gyroxanthin- the first allenic acetylenic carotenoid. Tetrahedron 56, 9047-9056.

Bodennec, G., Gentien, P., Parrish, C.C., Arzul, G., Youenou, A., Crassous, M.P., 1995. Production of suspected lipid phycotoxins by Gymnodinium cf. nagasakiense in batch cultures. In: Lassus, P., Arzul, G., Erard, E., Gentien, P., Marcaillou, C. (Eds.), Harmful Marine Algal Blooms. Intercept Ltd., Technique et Documentation, Lavoisler, pp. $407-412$.

Bols, N.C., Barlian, A., Chirino-Trejo, M., Caldwell, S.J., Goegan, P., Lee, L.E.J., 1994. Development of a cell line from primary cultures of rainbow trout, Oncorhynchus mykiss (Walbaum), gills. J. Fish. Dis 17, 601-611.

Brand, L.E., Campbell, L., Bresnan, E., 2012. Karenia: The biology and ecology of a toxic genus. Harmful Algae 14, 156-178.

Carreto, J.L., Seguel, M., Montoya, N.G., Clément, A., Carignan, M.O., 2001. Pigment profile of the ichthyotoxic dinoflagellate Gymnodinium sp. from a massive bloom in southern Chile. J. Plankton Res 23 (10), 1171-1175.

Chang, F.H., Zeldis, J., Gall, M., Hall, J., 2003. Seasonal and spatial variation of phytoplankton assemblages, biomass and cell size from spring to summer across the northeastern New Zealand continental shelf. J. Plankton Res. 35, 737-758.

Clément, A., Seguel, M., Arzul, G., Guzmán, L., Alarcón, C., 2001. A widespread outbreak of a haemolytic, ichthyotoxic Gymnodinium sp. in southern Chile. In: Hallegraeff, G.M., Blackburn, S.I., Bolch, C.J., Lewis, R.J. (Eds.), Harmful Algal Blooms 2000. Intergovernmental Oceanographic Commission, UNESCO, Paris, pp. 66-69.

Daugbjerg, N., Hansen, G., Larsen, J., Moestrup, $\varnothing$, 2000. Phylogeny of some of the major genera of dinoflagellates based on ultrastructure and partial LSU rDNA sequence data, including the erection of three new genera of unarmoured dinoflagellates. Phycologia 39 (4), 302-317.

Davis, C.C., 1948. Gymnodinium brevis sp. nov., a cause of discolored water and animal mortality in the Gulf of Mexico. Bot. Gaz 109, 358-360. 
Dayeh, V.R., Schirmer, K., Lee, L.E.J., Bols, N.C., 2005. Rainbow trout gill cell line microplate cytotoxicity test. In: Blaise, C., Férard, J.F. (Eds.), Small-Scale Fresh-water Toxicity Investigations. Springer, The Netherlands, pp. 473-503.

de Salas, M.F., Rhodes, L.L., MacKenzie, L.A., Adamson, J.E., 2005. Gymnodinoid genera Karenia and Takayama (Dinophyceae) in New Zealand coastal waters. N. Z. J. Mar. Fresh 39, 135-139.

Dorantes-Aranda, J.J., Waite, T.D., Godrant, A., Rose, A., Tovar, C.D., Woods, G.M., Hallegraeff, G.M., 2011. Novel application of a fish gill cell line assay to assess ichthyotoxicity of harmful marine microalgae. Harmful Algae 10, 366-373.

Dorantes-Aranda, J.J., Seger, A., Mardones, J.I., Nichols, P.D., Hallegraeff, G.M., 2015. Progress in understanding algal bloom-mediated fish kills: the role of superoxide radicals, phycotoxins and fatty acids. PLOS ONE 10 (7), e0133549.

Edvardsen, B., Shalchian-Tabrizi, K., Jakobsen, K.S., Medlin, L.K., Dahl, E., Brubak, S., Paasche, E., 2003. Genetic variability and molecular phylogeny of Dinophysis species (Dinophyceae) from Norwegian waters inferred from single cell analyses of rDNA. J. Phycol 39, 395-408.

Fossat, B., Porthe-Nibelle, J., Sola, F., Masoni, A., Gentien, P., Bodennec, G., 1999. Toxicity of fatty acid 18:5n 3 from Gymnodinium cf. mikimotoi: II intracellular $\mathrm{pH}$ and $\mathrm{K}^{+}$uptake in isolated trout hepatocytes. J. Appl. Toxicol 19, 275-278.

Gallardo-Rodríguez, J.J., Astuya-Villalón, A., Avello, V., Llanos-Rivera, A., Krock, B. Agurto-Muñoz, C., Sánchez-Mirón, A., García-Camacho, F., 2020. Production of extracts with anaesthetic activity from the culture of Heterosigma akashiwo in pilot-scale photobioreactors. Algal Res 45, 101760.

Gentien, P., Lunven, M., Lazure, P., Youenou, A., Crassous, M.P., 2007. Motility and autotoxicity in Karenia mikimotoi (Dinophyceae). Philos. Trans. R. Soc. B 362, 1937-1946.

Godrant, A., Rose, A.L., Sarthou, G., Waite, T.D., 2009. New method for the determination of extracellular production of superoxide by marine phytoplankton using the chemiluminescence probes MCLA and red-CLA. Limnol. Oceanogr. Methods 7, 682-692.

Guillard, R.R.L., Ryther, J.H., 1962. Studies of marine planktonic diatoms. I. Cyclotella nana Hustedt and Detonula confervacea Cleve. Can. J. Microbiol 8, 229-239.

Guillou, L., Nezan, E., Cueff, V., Denn, E.E.L., Cambon-Bonavita, M.A., Gentien, P., Barbier, G., 2002. Genetic diversity and molecular detection of three toxic dinoflagellate genera (Alexandrium, Dinophysis, and Karenia) from French coasts. Protist 153 (3), 223-238.

Guindon, S., Dufayard, J.F., Lefort, V., Anisimova, M., Hordijk, W., Gascuel, O., 2010. New algorithms and methods to estimate maximum- likelihood phylogenies: assessing the performance of PhyML 3.0. Syst. Biol. 59, 307-321.

Guzmán, L., Espinoza, O., Carbonell, P., Martínez, R., Pizarro, G., Salgado, P., Mardones, J.I., Fuenzalida, G., Besoain, V., Cascales, E., Palma, M., Alarcón, C., Pacheco, H., Toro, C., Iriarte, L., Muñoz, V., Cornejo, M., Labra, G., López, L., Cáceres, J., Correa, K., Olivares, B., González, R., Soto, C., Lincoqueo, L., 2020. Programa de manejo y monitoreo de las mareas rojas en el Sistema de fiordos y canals de Chile. Etapa XIII 2019-2020, Informe Final. Ministerio de economía, Fomento y Turismo-Subsecretaría de Economía y EMT, pp. 133.

Hallegraeff, G.M., Dorantes-Aranda, J.J., Mardones, J.I., Seger, A., 2017. Review of progress in our understanding of fish-killing microalgae: implications for management and mitigation. In: Proença, L.A.O., Hallegraeff, G.M. (Eds.), Marine and Freshwater Harmful Algae. Proceedings of the 17th International Conference on Harmful Algae. International Society for the Study of Harmful Algae and Intergovernmental Oceanographic Commission of UNESCO, Paris, pp. 148-153.

Hansen, G., Daugbjerg, N., Henricksen, P., 2000. Comparative study of Gymnodinium mikimotoi and Gymnodinium aureolum, comb. nov. (=Gyrodinium aureolum) based on morphology, pigment composition, and molecular data. J. Phycol 36, 394-410.

Hansen, G., Erard-Le Denn, E., Daugbjerg, N., Rodriguez, F., 2004. Karenia selliformis responsible for the fish-kills in the Gulf of Gabès, Tunisia 1994. In: Book of abstracts $11^{\text {th }}$ International conference on Harmful Algae. Cape Town, South Africa November 15-19.

Harju, K., Koskela, H., Kremp, A., Suikkanen, S., de la Iglesia, P., Miles, C.O., Krock, B., Vanninen, P., 2016. Identification of gymnodimine D and presence of gymnodimine variants in the dinoflagellate Alexandrium ostenfeldii from the Baltic Sea. Toxicon 112, $68-76$.

Haywood, A.J., 2001. Morphological and molecular systematics of unarmoured dinoflagellates (Gymnodiniales, Dinophyceae) from New Zealand. University of Auckland, New Zealand, pp. 255 (Ph.D. Thesis).

Haywood, A.J., Steidinger, K.A., Truby, E.W., 2004. Comparative morphology and molecular phylogenetic analysis of three new species of the genus Karenia (Dinophyceae) from New Zealand. J. Phycol 40, 165-179.

Haywood, A.J., Scholin, C.A., Marin, R., Steidinger, K.A., Heil, C., Ray, J., 2007. Molecular detection of the brevetoxin-producing dinoflagellate Karenia brevis and closely related species using rRNA-targeted probes and a semiautomated sandwich hybridization assay. J. Phycol 43 (6), 1271-1286.

Heil, C.A., Glibert, P.M., Al-Sarawi, M.A., Faraj, M., Behbehani, M., Husain, M., 2001. First record of a fish-killing Gymnodinium sp. bloom in Kuwait Bay, Arabian Sea: chronology and potential causes. Mar. Ecol. Prog. Ser. 214, 15-23.

Ihaka, R., Gentleman, R., 1996. A language for data analysis and graphics. J. Comput. Graph. Stat. 5, 299-314.

Ishida, K., Green, B.R., 2002. Second- and third-hand chloroplasts in dinoflagellates: phylogeny of oxygen-evolving enhancer 1 (PsbO) protein reveals replacement of a nuclear-encoded plastid gene by that of a haptophyte tertiary endosymbiont. Proc. Natl. Acad. Sci. USA 99, 9294-9299.

Kharrat, R., Servent, D., Girard, E., Ouanounou, G., Amar, M., Marrouchi, R., Benoit, E., Molgó, J., 2008. The marine phycotoxin gymnodimine targets muscular and neuronal nicotinic acetylcholine receptor subtypes with high affinity. J. Neurochem. 107, 952-963.

Kubanek, J., Hicks, M.K., Naar, J., Villareal, T.A., 2005. Does the red tide dinoflagellate
Karenia brevis use allelopathy to outcompete other phytoplankton? Limnol. Oceanogr 50 (3), 883-895.

Landsberg, J.H., Steidinger, K.A., 1998. A historical review of Gymnodinium breve red tide implicated in mass mortalities of the manatee (Trichechus manatus latirostris) in Florida, USA. In: Reguera, B., Bianco, J., Fernandez, M.L., Wyatt, T (Eds.), Harmful Algae Proc. VII Int. Conf. on Harmful Algae, Vigo, 1997, Xunta de Galicia, Intergovernmental Oceanographic Commission of UNESCO. Paris. pp. 97-100.

Larkin, M.A., Blackshields, G., Brown, N.P., Chenna, R., McGettigan, P.A., McWilliams, H., Valentin, F., Wallace, I.M., Wilm, A., Lopez, R., Thompson, J.D., Gibson, T.J., Higgins, D.G., 2007. Clustal W and Clustal X version 2.0. Bioinformatics 23, 2947-2948.

Lavaud, J., Rousseau, B., Etienne, A-L., 2004. General features of photoprotection by energy dissipation in planktonic diatoms (Bacillariophyceae). J. Phycol. 40, 130-137.

Li, S., Cen, J., Wang, J., Lv, S., 2018. Study on acute toxicity of two Karenia (Dinophyceae) species to rotifer Brachionus plicatilis. Mar. Environ. Sci 37 (1), 61-66.

Magaña, H.A., Villareal, T.A., 2006. The effects of environmental factors on the growth rate of Karenia brevis (Davis) G. Hansen and Moestrup. Harmful Algae 5, 192-198.

Mardones, J.I., Dorantes-Aranda, J.J., Nichols, P.D., Hallegraeff, G.M., 2015. Fish gill damage by the dinoflagellate Alexandrium catenella from Chilean fjords: Synergistic action of ROS and PUFA. Harmful Algae 49, 40-49.

Mardones, J.I., Shabala, L., Shabala, S., Dorantes-Aranda, J.J., Seger, A., Hallegraeff, G.M., 2018. Fish gill damage by harmful microalgae newly explored by microelec trode ion flux estimation techniques. Harmful Algae 80, 55-63.

Mardones, J.I., Fuenzalida, G., Zenteno, K., Alves-de-Souza, C., Astuya, A., DorantesAranda, J.J., 2019. Salinity-growth response and ichthyotoxic potency of the Chilean Pseudochattonella verruculosa. Front. Mar. Sci 6, 24. https://doi.org/10.3389/fmars. 2019.00024.

Mardones, J.I., 2020. Screening of Chilean fish-killing microalgae using a cell line-based assay. Lat. Am. J. Aquat. Res. 48 (2). https://doi.org/10.3856/vol48-issue2Fulltext-X.

Martens, H., Tillmann, U., Harju, K., Dell'Aversano, C., Tartaglione, L., Krock, B., 2017. Toxin variability estimations of 68 Alexandrium ostenfeldii (Dinophyceae) strains from the Netherlands reveal a novel abundant gymnodimine. Microorganisms 5 (2), 29.

McNabb, P.S., Selwood, A.L., Van Ginkel, R., Boundy, M., Holland, P.T., 2012. Determination of brevetoxins in shellfish by LC/MS/MS: single-laboratory validation. J. AOAC Int. 95 (4), 1097-1105.

Medhioub, A., Medhioub, W., Amzil, Z., Sibat, M., Bardouil, M., Ben Neila, I., Mezghani, S., Hamza, A., Lassus, P., 2009. Influence of environmental parameters on Karenia selliformis toxin content in culture. Cah. Biol. Mar 50, 333-342.

Miles, C.O., Wilkins, A.L., Stirling, D.J., Mackenzie, A.L., 2000. New analogue of gymnodimine from a Gymnodinium sp. J. Agric. Food Chem 48, 1373-1376.

Miles, C.O., Wilkins, A.L., Stirling, D.J., Mackenzie, A.L., 2003. Gymnodimine C, an isomer of gymnodimine B, from Karenia selliformis. J. Agric. Food Chem 51, 4838-4840.

Molgó, J., Girard, E., Benoit, E., 2007. Cyclic imines: an insight into this memrging group of bioactive marine toxins. In: Botana, L.M. (Ed.), Phycotoxins: Chemistry and Biochemistry. Blackwell Publishing, pp. 319-335.

Mooney, B.D., Nichols, P.D., de Salas, M.F., Hallegraeff, G.M., 2007. Lipid, fatty acid and sterol composition of eight species of Kareniaceae (Dinophyta): chemotaxonomy and putative phycotoxins. J. Phycol 43, 101-111.

Mooney, B.D., Dorantes-Aranda, J.J., Place, A.R., Hallegraeff, G., 2011. Ichthyotoxicity of gymnodinioid dinoflagellates: PUFA and superoxide effects in sheepshead minnow larvae and rainbow trout gill cells. Mar. Ecol. Prog. Ser. 426, 213-224.

Mountfort, D., Beuzenberg, V., MacKenzie, L., Rhodes, L., 2006. Enhancement of growth and gymnodimine production by the marine dinoflagellate, Karenia selliformis. Harmful Algae 5, 658-664.

Munday, R., Towers, N.R., Mackenzie, L., Beuzenberg, V., Holland, P.T., Miles, C.O., 2004. Acute toxicity of gymnodimine to mice. Toxicon 44, 173-178.

Pagé, B., Pagé, M., Noël, C., 1993. A new fluorometric assay for cytotoxicity measurements in vitro. Int. J. Oncol. 3, 473-476.

Posada, D., 2008. jModelTest: phylogenetic model averaging. Mol. Biol. Evol 25, 1253-1256.

Prince, E.K., Poulson, K.L., Myers, T.L., Sieg, R.D., Kubanek, J., 2010. Characterization of allelopathic compounds from the red tide dinoflagellate Karenia brevis. Harmful Algae $10,39-48$.

Richardson, T.L., Pinckney, J.L., 2004. Monitoring of the toxic dinoflagellate Karenia brevis using gyroxanthin-based detection methods. J. Appl. Phycol 16, 315-328.

Ronquist, F., Huelsenbeck, J.P., 2003. MRBAYES 3: Bayesian phylogenetic inference under mixed models. Bioinformatics 19, 1572-1574.

Salgado, P., Riobó, P., Rodríguez, F., Franco, J.M., Bravo, I., 2015. Differences in the toxin profiles of Alexandrium ostenfeldii (Dinophyceae) strains isolated from different geographic origins: Evidence of paralytic toxin, spirolide, and gymnodimine. Toxicon 103, 85-98.

Sanz, N., García-Blanco, A., Gavalás-Olea, A., Loures, P., Garrido, J.L., 2015. Phytoplankton pigment biomarkers: HPLC separation using a pentafluorophenyloctadecyl silica column. Methods in Ecology and Evolution 6, 1199-1209.

Satake, M., Shoji, M., Oshima, Y., Naoki, H., Fujita, T., Yasumoto, T., 2002. Gymnocin-A, a cytotoxic polyether from the notorious red tide dinoflagellate, Gymnodinium mikimotoi. Tetrahedron Lett 43 (33), 5829-5832.

Satake, M., Tanaka, Y., Ishikura, Y., Oshima, Y., Naoki, H., Yasumoto, T., 2005. Gymnocin-B with the largest contiguous polyether rings from the red tide dinoflagellate, Karenia (formerly Gymnodinium) mikimotoi. Tetrahedron Lett 46 (20), 3537-3540.

Scholin, C.A., Herzog, M., Anderson, D.M., 1994. Identification of group and strain specific genetic markets for globally distributed Alexandrium (Dinophyceae). II. 
Sequence analysis of a fragment of the LSU rRNA gene. J. Phycol 30, 999-1011.

Seki, T., Satake, M., Mackenzie, L., Kaspar, H.F., Yasumoto, T., 1995. Gymnodimine, a new marine toxin of unprecedented structure isolated from New Zealand oysters and the dinoflagellate, Gymnodinium sp. Tet. Lett 36, 7093-7096.

Silke, J., O'Beirn, F., Cronin, M., 2005. Karenia: an exceptional dinoflagellate bloom in western Irish waters, summer 2005. Marine Environment and Health Series 21, 44.

Sola, F., Masoni, A., Fossat, B., Perthe-Nibelle, J., Gentien, P., Bodennec, G., 1999. Toxicity of fatty acid 18:5n3 from Gymnodinium cf. mikimotoi: morphological and biochemical aspects on Dicentrarchus labrax gills and intestine. J. Appl. Toxicol 19, 279-284.

Steidinger, K.A., Ingle, R.M., 1972. Observations on the 1971 summer red tide in Tampa Bay, Florida. Environ. Lett 3 (4), 271-278.

Steidinger, K.A., Landsberg, J.H., Flewelling, L.J., Kirkpatrick, B.A., et al., 2008a. Toxic dinoflagellates. In: Walsh, P.J. (Ed.), Oceans and Human Health. Academic Press, Burlington, MA, pp. 239-256.

Steidinger, K.A., Wolny, J.L., Haywood, A.J., 2008b. Identification of Kareniaceae (Dinophyceae) in the Gulf of Mexico. Nova Hedwigia, Beiheft 133, 269-284.

Strangman, W., Anttila, M., Tomas, C., Wright, J., 2016. (5S)-5-

[(4aR,8aS,9E,11S,13R,14S,16R,17R,19S)-11,19-Dihydroxy-8,10,13,16-tetramethyl18 methylidene-3,4,5,6,8a,11,12,13,14,15,16,17,18,19,20,21-hexadecahydro-2H14,17 epoxybenzo[2,3] cyclohexadeca[1,2-b]pyridine-7-yl]-3-methylfuran-2(5H)-one (12Methylgymnodimine B). Molbank 2016 (2), M896.

Suzuki, R., Ishimaru, T., 1992. Characteristics of photosynthetic pigment composition of Gymnodinium mikimotoi Miyake et Kominami ex Oda. J. Oceanogr 48, 367-375.

Takishita, K., Ishida, K.-I., Maruyama, T., 2004. Phylogeny of nuclear-encoded plastidtargeted GAPDH gene supports separate origins for the peridinin- and fucoxanthin derivative-containing plastids of dinoflagellates. Protist 155, 447-458.

Tangen, K., Bjørnland, T., 1981. Observations on pigment and morphology of Gyrodinium aureolum Hulbert, a marine dinoflagellate containing 19'-hexa- noyl-oxyfucoxanthincontaining dinoflagellates have tertiary plastids of haptophyte origin. J. Plankton Res
3, 389-401.

Tatters, A.O., Harris, I., Muhlstein, H.I., Tomas, C.R., 2010. The hemolytic activity of Karenia selliformis and two clones of Karenia brevis throughout a growth cycle. Journal of Applied Phycology 22, 435-442.

Trainer, V., Moore, S.K, Hallegraeff, G., Kudela, R.M., Clément, A., Mardones, J.I. Cochlan, W.P., 2019. Pelagic harmful algal blooms and climate change: Lessons from nature's experiments with extremes. Harmful Algae, 101591. https://doi.org/10. 1016/j.hal.2019.03.009.

Trefault, N., Krock, B., Delherbe, N., Cembella, A., Vásquez, M., 2011. Latitudinal transects in the southeastern Pacific Ocean reveal a diverse but patchy distribution of phycotoxins. Toxicon 58, 389-397.

Uribe, J.C., Ruíz, M., 2001. Gymnodinium brown tide in the Magellanic fjords, southern Chile. Rev. Biol. Mar. Oceanogr 36, 155-164.

Vandersea, M.W., Kibler, S.R., Van Sant, S.B., Tester, P.A., Sullivan, K., Eckert, G., Cammarata, C., Reece, K., Scott, G., Place, A., Holderied, K., Hondolero, D., WaineLitaker, R., 2017. qPCR assays for Alexandrium fundyense and A. ostenfeldii (Dinophyceae) identified from Alaskan waters and a review of species-specific Alexandrium molecular assays. Phycologia 56, 303-320.

Van Wagoner, R.M., Misner, I., Tomas, C.R., Wright, J.L.C., 2011. Occurrence of 12 methylgymnodimine in a spirolide-producing dinoflagellate Alexandrium peruvianum and the biogenic implications. Tetrahedron Lett 52, 4243-4246.

Yamaguchi, H., Hirano, T., Yoshimatsu, T., Tanimoto, Y., Matsumoto, T., Suzuki, S., Hayashi, Y., Urabe, A., Miyamura, K., Sakamoto, S., Yamaguchi, M., Tomaru, Y., 2016. Occurrence of Karenia papilionacea (Dinophyceae) and its novel sister phylotype in Japanese coastal waters. Harmful Algae 57, 59-68.

Zapata, M., 2005. Recent advances in pigment analysis as applied to picophytoplankton. Vie Et Milieu 55, 233-248.

Zurhelle, C., Nieva, J., Tillmann, U., Harder, T., Krock, B., Tebben, J., 2018. Identification of Novel Gymnodimines and Spirolides from the Marine Dinoflagellate Alexandrium ostenfeldii. Mar. Drugs 16 (11), 446. 